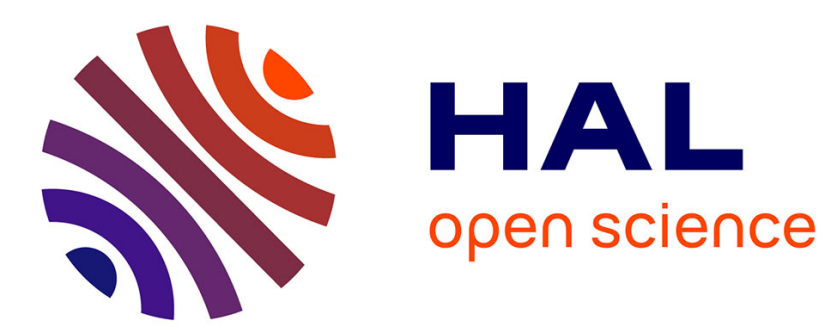

\title{
Multichannel optical sensor to quantify particle stability under seepage flow
}

\author{
Didier Marot, Fateh Bendahmane, Jean Marc Konrad
}

\section{To cite this version:}

Didier Marot, Fateh Bendahmane, Jean Marc Konrad. Multichannel optical sensor to quantify particle stability under seepage flow. Canadian Geotechnical Journal, 2011, 48 (12), pp.1772-1787. 10.1139/T11-074 . hal-01004903

\section{HAL Id: hal-01004903 https://hal.science/hal-01004903}

Submitted on 10 Mar 2018

HAL is a multi-disciplinary open access archive for the deposit and dissemination of scientific research documents, whether they are published or not. The documents may come from teaching and research institutions in France or abroad, or from public or private research centers.
L'archive ouverte pluridisciplinaire HAL, est destinée au dépôt et à la diffusion de documents scientifiques de niveau recherche, publiés ou non, émanant des établissements d'enseignement et de recherche français ou étrangers, des laboratoires publics ou privés. 


\title{
Multichannel optical sensor to quantify particle stability under seepage flow
}

\author{
Didier Marot, Fateh Bendahmane, and Jean-Marie Konrad
}

\begin{abstract}
An optical sensor was designed to measure the fine solid particles concentration contained in a fluid flow. This sensor is composed of four light-emitting diodes and four associated light-dependent resistors, allowing the measurement of fluid transparency. Given the small device dimensions, it can be placed close to the particles exit from the specimen. The optical sensor is able to instantaneously measure a large range of clay or silt concentrations in the effluent, without a signifi-cant influence of flow rate. The presence of sand grains in fluid flow can be detected. The use of this sensor with a specific triaxial device allows precise characterization of the initiation and development of the suffusion process on clayey sand specimens. It is shown that suffusion of clay particles induces a decrease of hydraulic conductivity, which is due to a diffuse process of eroded particles filtration. Clay suffusion and filtration processes are influenced by grainsize distribution and also by grain shape of the coarse fraction. Under a high hydraulic gradient, clay suffusion can be accompanied by sand ero-sion. The critical value of mean pore velocity to initiate clay suffusion was determined for the types of soils.
\end{abstract}

Key words: laboratory testing, seepage, transparency, solid particle concentration, suffusion, pore velocity.

Résumé : Un capteur optique a été conçu pour mesurer la concentration en particules fines d'un écoulement de fluide. Ce capteur est composé de quatre diodes émettrices de lumière, et de quatre photo résistances associées qui mesurent la transpa-rence du fluide. Puisque l'appareil est de faible dimension, il peut être placé près de l'endroit où les particules sortent de l'échantillon. Le capteur optique peut mesurer instantanément une large gamme de concentrations d'argile ou de limon dans l'effluent sans influence significative du taux d'écoulement. La présence de grains de sable dans l'écoulement peut être dé-tectée. L'utilisation de ce capteur avec un appareil triaxial spécifique permet de caractériser précisément l'initiation et le dé-veloppement du processus de suffusion sur des échantillons de sable argileux. Il est démontré que la suffusion des particules argileuses induit une diminution de la conductivité hydraulique en raison d'un processus diffus de filtration des particules érodées. La suffusion de l'argile et le processus de filtration sont influencés par la granulométrie et aussi par la forme de la fraction grossière. Sous un gradient hydraulique élevé, la suffusion de l'argile peut être accompagnée par l'érosion du sable. La valeur critique de la vitesse moyenne dans les pores pour initier la suffusion de l'argile a été déterminée pour les types de sol.

Mots-clés : essais en laboratoire, écoulement, transparence, concentration en particules solides, suffusion, vitesse dans les pores.

\section{Introduction}

Detection of the initiation of solid particle transport in compacted soils subjected to seepage and determination of solid particle concentration in fluid flow are important, notably in the field of soil erosion. For instance, due to seepage flow, the detachment and the migration of particles can result in considerable damage in earth structures (Foster et al. 2000).

In earth structures and their foundations, two types of erosion can be distinguished (Agence nationale de la recherche

D. Marot and F. Bendahmane. Institut de recherche en génie civil et mécanique, Université de Nantes, 58 rue Michel Ange, BP 420, 44606 Saint-Nazaire CEDEX, France.

J.-M. Konrad. Département de génie civil, Pavillon Pouliot, Université Laval, QC G1V 0A6, Canada.

Corresponding author: D. Marot (e-mail: didier.marot@univnantes.fr).
2009): (i) suffusion, also named internal instability, which takes place inside the soil matrix; (ii) interface erosion, which occurs at an interface between two types of soil or at the surface between soil and water, where the surface is relatively large compared to the grain scale. In the suffusion process, finer particles of a soil migrate within its own pore spaces. These fine particles can be cohesionless particles or clay particles. The amount of stripped material can be very small, and the process of fine particle erosion can be very slow and diffuse without any significant soil volume change. Because of these characteristics, tests that determine the initiation and development of solid transport are not easy to perform. As a result, visual determination of the effluent turbidity or measurement of variation in local hydraulic gradient are frequently used to estimate the onset and evolution of the erosion process. However, these measurements are generally too inaccurate to definitely characterize erosion initiation.

This paper describes a multichannel optical sensor developed to measure, in real time, the quantity of eroded fine particles for a soil specimen subjected to seepage. This novel optical sensor instantaneously measures the transparency of 
the effluent fluid during the percolation test by means of different light-emitting diodes (LEDs) and associated light-dependent resistors (LDRs). Furthermore, it is possible to distinguish clay particles and sand grains due to the output signal differences between two LEDs. By using a specific triaxial device equipped with this optical sensor, an experimental test program was performed to study the suffusion process in different reconstituted soils composed of kaolin and two types of sand. The results are discussed in terms of influence of the soil coarse fraction and critical value of mean pore velocity required to initiate the detachment of fine particles under seepage flow.

\section{Background on experimental testing devices for the study of suffusion}

For the characterization of initiation and development of the suffusion process, most of the experimental devices contained a rigid wall cylinder. A sample can be subjected to a unidirectional flow in either an upward direction (Skempton and Brogan 1994; Wan and Fell 2004; Li 2008) or in a downward direction (Kenney and Lau 1985; Reddi et al. 2000; Moffat and Fannin 2006; Wan and Fell 2008). The main difficulty of the test devices is related to erosion quantification, which must be accurate enough to detect both the erosion initiation and to be able to measure different ranges of erosion rate.

The onset of suffusion is generally detected from measurements of variation of local hydraulic gradient or by visual observation of the effluent turbidity. Different studies (Moffat and Fannin 2006; Li 2008; Sail et al. 2011) show that when the average hydraulic gradient and the local hydraulic gradient in a part of a tested sample are constant, at the same moment in another part of the same sample, the local hydraulic gradient can vary by several orders of magnitude. Thus, the detection of initiation of soil particle migration based on the variation of local hydraulic gradient may depend on sample length and on the distance between two pressure transducers or piezometers. In a downward flow test, the visual detection of fine particles detachment is not easy to perform with accuracy. The use of a turbidimeter allows measuring the effluent turbidity. Unfortunately, this type of device requires an upward flow or horizontal flow, which may generate a process of fines sedimentation between sample exit and turbidimeter. This, in turn, creates a bias in the measurements. An upward flow test makes it easier to observe fine particles detachment, but the accuracy of erosion rate measurement decreases because of the detached particles sedimentation process at the end of the upper sample.

For all devices quoted above, the sample can be weighed to determine the erosion rate. During downward flow tests, Li (2008) quantified the rate of erosion by collecting the eroded particles in two collection troughs. It is clear that instantaneous measurement of the erosion rate allows to better characterize the loss of mass compared to approaches based solely on a few eroded mass measurements or initial and final sample mass. The proposed multichannel optical sensor is able to measure the erosion rate of clay particles or cohesionless fine particles continuously, and its accuracy allows a fairly precise detection of erosion initiation. The optical prin- ciple on which the sensor is based and the sensor calibration are described.

\section{Optical sensor design and calibration}

Following the description of the sensor characteristics, the methodology to use the sensor for different types of soils is described.

\section{Optical sensor characteristics}

As an intensity light, $I_{0}$, traverses a homogeneous solution of suspended solid particles, the light intensity is attenuated both by absorption and by scattering to an intensity, I (Bohren and Huffman 1998). Thomas and Burgess (2007) indicated that the change in intensity of the incident light caused by a low concentration, $C$, of an absorbing solution is given by Beer's law, and the change induced by the thickness, $b$, of the absorbing solution is given by Lambert's law. The combination of these laws gives the well-known Beer-Lambert law:

$$
\text { [1] } \quad A_{\lambda}=\log \frac{I_{0}}{I}=\varepsilon_{\lambda} b C
$$

where $A_{\lambda}$ is the absorbance, $\varepsilon_{\lambda}$ is the molar absorption coefficient, $b$ is the thickness of the absorbing solution, and $C$ is the solution concentration. The values of $\varepsilon_{\lambda}$ and thus $A_{\lambda}$ are wavelength, $\lambda$, dependent.

The principle of the proposed optical sensor is based on the Beer-Lambert law for a unique thickness of the absorbing solution. At a given wavelength and for a single component, absorbance is then a linear function of concentration of this component. Thus, the measurement of change in intensity can be used for the calculation of the solid concentration.

The experimental device used in this study consists of an opaque polyvinyl chloride (PVC) cylinder, $60 \mathrm{~mm}$ in length $(L)$ and $50 \mathrm{~mm}$ in diameter $(d)$, as shown on Fig. 1.

Along the axis of the PVC cylinder, a $6 \mathrm{~mm}$ diameter hole allows the insertion of a glass pipe inside the cylinder in which the mixture of water and solid particles can flow in a downward direction. A glass pipe (inside diameter, $d_{\text {int }}=$ $4 \mathrm{~mm}$ ) is used to avoid any variation of its transparency during the test duration. The PVC cylinder is equipped with four LEDs. An LED consists of a semiconductor diode that emits light when an electric current passes through it. A small change in power supply voltage can lead to a large change in current, and a small amount of voltage rating can damage the LED. Hence, a resistor connected in series with each LED permits to drive the four LEDs with a voltage much lower than the maximum rating.

The optical sensor uses two red LEDs, a blue LED, and a green LED. The first red LED has a $660 \mathrm{~nm}$ peak wavelength and a luminosity intensity of $1000 \mathrm{mcd}$ at $20 \mathrm{~mA}$, and the second red LED is used with a higher luminosity intensity of $2800 \mathrm{mcd}$ at $20 \mathrm{~mA}$. The blue LED has a $470 \mathrm{~nm}$ peak wavelength and a luminous intensity of $1200 \mathrm{mcd}$ at $20 \mathrm{~mA}$. The green LED has a $525 \mathrm{~nm}$ peak wavelength and a luminous intensity of $1500 \mathrm{mcd}$ at $20 \mathrm{~mA}$.

Opposite to each LED, an LDR is placed to measure the optical signal transmitted through the glass pipe. If light strikes such type of high-resistance semiconductor, some electrons of the semiconductor are excited and conduct electricity. Therefore, the LDR resistance, $R_{\mathrm{LDR}}$, decreases ac- 
Fig. 1. Schematic diagram of optical sensor. $d_{\text {int }}$, inside diameter.

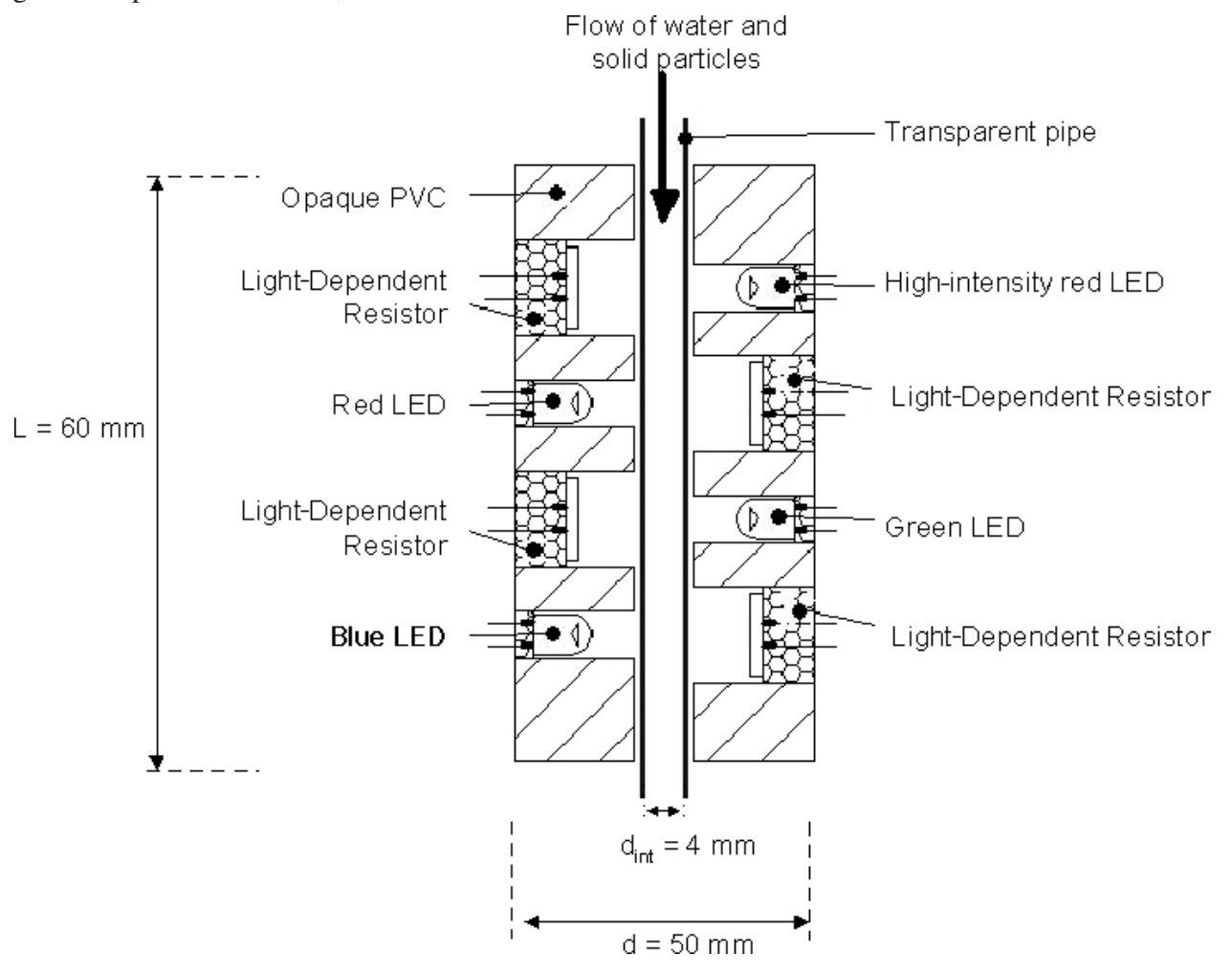

cording to the incident light intensity. Figure 2 represents the complete schematic diagram of power supply and signal acquisition of each LDR.

When a resistor, $R$, is connected to the continuous voltage supply, $V_{\mathrm{CC}}$, and the LDR is connected to ground (GND), the output voltage, $V_{\text {out }}$, can be expressed by

$$
\text { [2] } \quad V_{\text {out }}=V_{\mathrm{cc}} \frac{R_{\mathrm{LDR}}}{R+R_{\mathrm{LDR}}}
$$

The output voltage, $V_{\text {out }}$, will increase with increasing LDR resistance as light intensity decreases. As soil particles in the effluent induce a decrease in the amount of light transmitted through the glass pipe, this connection configuration gives a rising output voltage with an increase of the solid concentration in the fluid.

To maximize the power transfer and to minimize the signal distortion, the basic electronic design is based on the principle of impedance matching. An operational amplifier (LM324N) is connected to the LDR output in the common collector (also named emitter follower) configuration (see Fig. 2). Thus, a small change on the LDR voltage will be replicated on the amplifier voltage output. A potentiometer is used as a voltage divider to manually adjust the output voltage according to the range of LDR output voltage. Finally, the impedance matching at the potentiometer output needs a second operational amplifier.

The optical sensor is connected to an analog-digital converter linked to a dedicated computer, which operates data acquisition and test monitoring.

According to eq. [2], the output voltage, $V_{\text {out }}$, of each LDR depends on the power voltage, $V_{\mathrm{CC}}$. Consequently, tests are analyzed in terms of relative output voltage, $U$, defined as the ratio of the output voltage to the power voltage. The adjustment performed with the potentiometer can lead to a relative output voltage higher than $1000 \mathrm{mV} / \mathrm{V}$. For the control case in which demineralized water is flowing through the glass pipe, the instantaneous values of the relative output voltage, $U$, for the four LEDs stay constant with elapsed time. The values of $U$ are sensibly the same for blue and green LEDs (817 and $824 \mathrm{mV} / \mathrm{V}$, respectively). The relative voltage for high-intensity red LED is about $1257 \mathrm{mV} / \mathrm{V}$, and it is higher for red LED (15 $441 \mathrm{mV} / \mathrm{V})$.

\section{Laboratory calibration}

A thorough laboratory calibration was undertaken to investigate the influence of clay concentration, flow rate, soil type, and grain size.

\section{Influence of clay concentration}

Thomas and Burgess (2007) indicated that the Beer-Lambert law (eq. [1]) is only true for low solid concentrations in a fluid. With a high solid concentration, multiple scattering is not negligible, and the Beer-Lambert law must be corrected. In the field of soil erosion tests (for example, hole erosion test, jet erosion test, suffusion test, among others), the range of solid concentration in a fluid can be relatively large. Thus, the optical sensor was calibrated using several mixtures composed of demineralized water and different amounts of kaolin clay.

The variation of the fluid concentration that passes through the pipe induces a variation of the transparency. The instantaneous solid particle mass concentration of this fluid is expressed by 
Fig. 2. Schematic diagram of power supply and acquisition system for each LDR. GND, ground; LM324N, operational amplifier; $V_{\mathrm{CC}}$, continuous voltage supply.

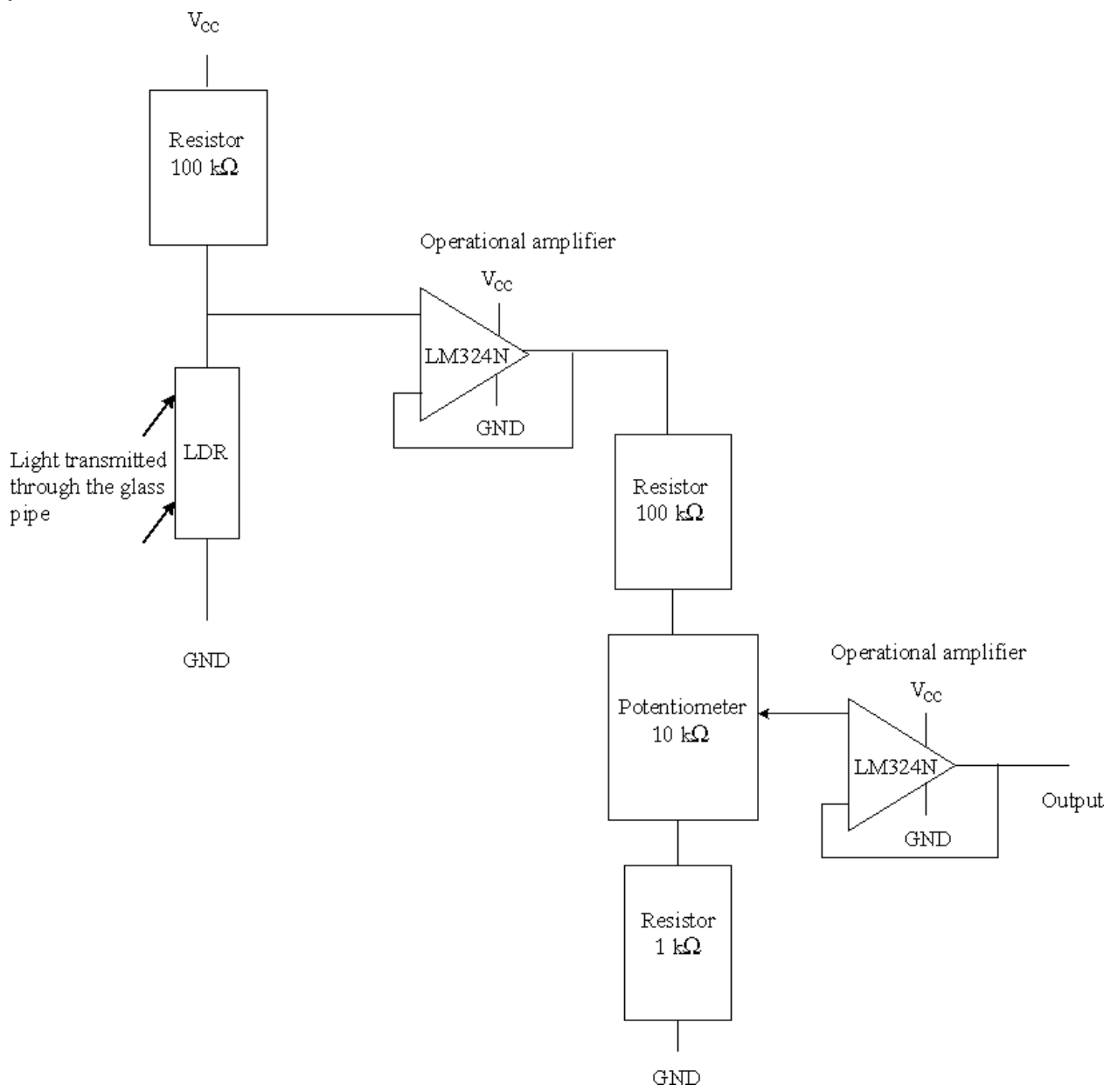

$$
\text { [3] } \quad C(t)=\frac{\Delta m_{\mathrm{C}}(t)}{\Delta m_{\mathrm{W}}(t)}
$$

where $m_{\mathrm{C}}$ is the mass of solid particles within the fluid, $m_{\mathrm{w}}$ is the water mass within the fluid, and $t$ is time.

After homogenization, the transparency of a fluid with a constant solid particle concentration is measured. A mixer is used to limit particle sedimentation, and a peristaltic pump maintains a constant fluid flow rate. A mass scale measures the cumulative mass of the solution that passes through the optical sensor (see Fig. 3).

Several tests were performed to measure the relative output voltage for the red, blue, and green LEDs, using different values of the kaolin concentration up to $90 \mathrm{mg} / \mathrm{g}$. Tests were realized with a vertical fluid seepage in the downward direction.

Figure 4 shows the relative output voltage for the four LEDs in function of kaolin concentration. The relative output voltage for the red LED increases sharply between 15441 and $29000 \mathrm{mV} / \mathrm{V}$ for increasing kaolin concentrations up to $7 \mathrm{mg} / \mathrm{g}$. For values of kaolin concentrations larger than $7 \mathrm{mg} / \mathrm{g}$, the output signal stays constant and is independent of the solid particle concentration. For the same range $(0-90 \mathrm{mg} / \mathrm{g})$ of kaolin concentrations, the relative output voltage for the highintensity red LED increases between 1257 and $15000 \mathrm{mV} / \mathrm{V}$. A polynomial correlation between high-intensity red LED output signal and kaolin concentrations can be expressed with correlation coefficient, $R^{2}=0.99$, and a number of individual tests, $N=19$ (see equation in Fig. 4).

Thus, by the measurement of relative output voltage for the high-intensity red LED, it is possible to determine the kaolin concentration. For a kaolin concentration higher than $12 \mathrm{mg} / \mathrm{g}$, the relative error in the calculation of kaolin concentration is lower than $3 \%$. For a kaolin concentration up to $12 \mathrm{mg} / \mathrm{g}$, the maximum relative error is $15 \%$.

For the green and blue LEDs, it is also possible to determine a correlation between their relative output voltage and kaolin concentration. However, these correlations will not be used because the obtained relative error for calculated kaolin concentration is higher than that for red LEDs.

With the objective to minimize the relative error in the determination of a low kaolin concentration in a flowing fluid, the relative output voltages for the four LEDs are plotted for a kaolin concentration smaller than $12 \mathrm{mg} / \mathrm{g}$ on Fig. 5 .

For a kaolin concentration up to $12 \mathrm{mg} / \mathrm{g}$, the high-intensity red LED output signal, $U_{\mathrm{HI}}$ red, is characterized by a linear increase with increasing kaolin concentration. A linear correlation with the kaolin concentration is expressed by

[4] $U_{\mathrm{HI} \text { red }}[\mathrm{mv} / \mathrm{V}]=460 C[\mathrm{mg} / \mathrm{g}]+1257$

$$
\left(R^{2}=0.99, \quad N=13\right)
$$


Fig. 3. Schematic representation of apparatus used for optical sensor calibration.

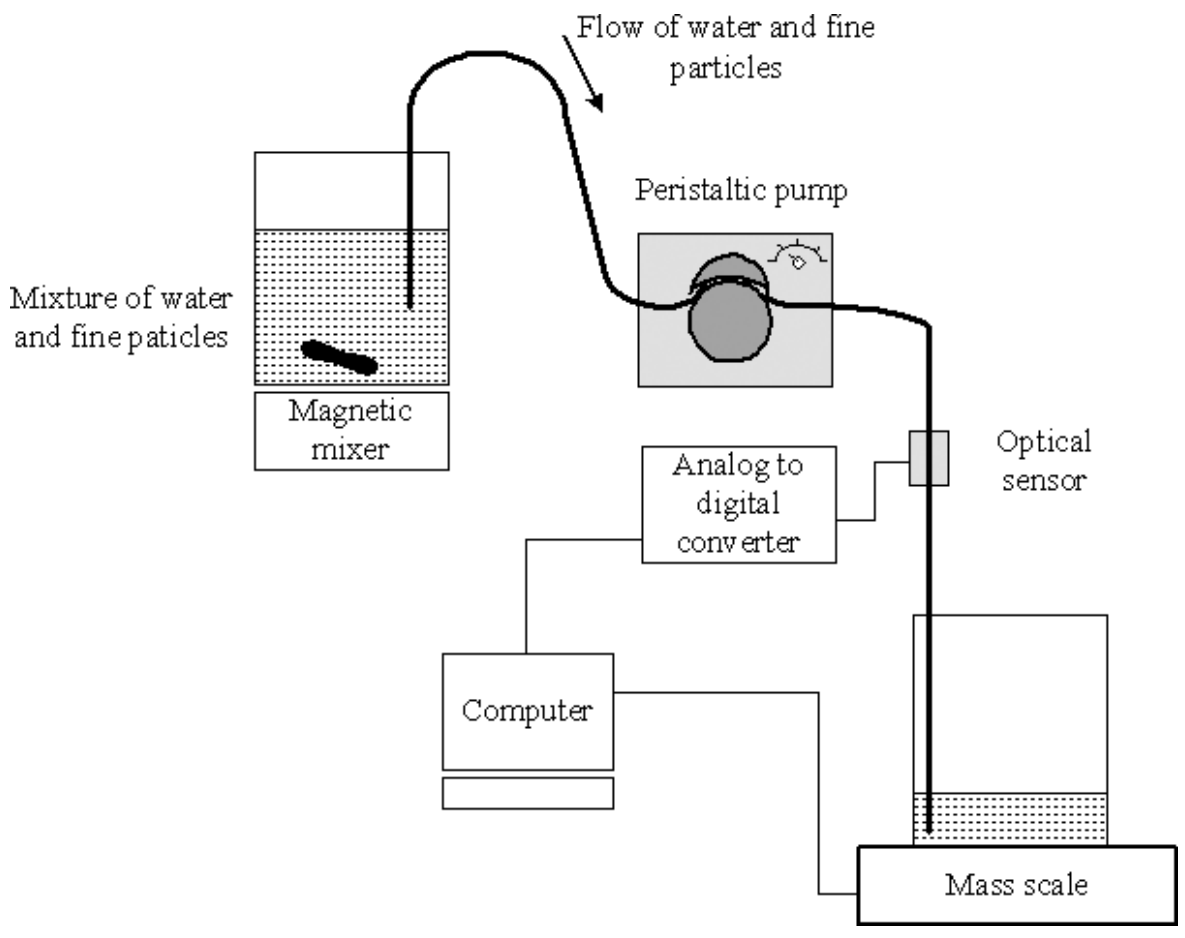

Fig. 4. Relative output voltage for the four LEDs versus kaolin concentration.

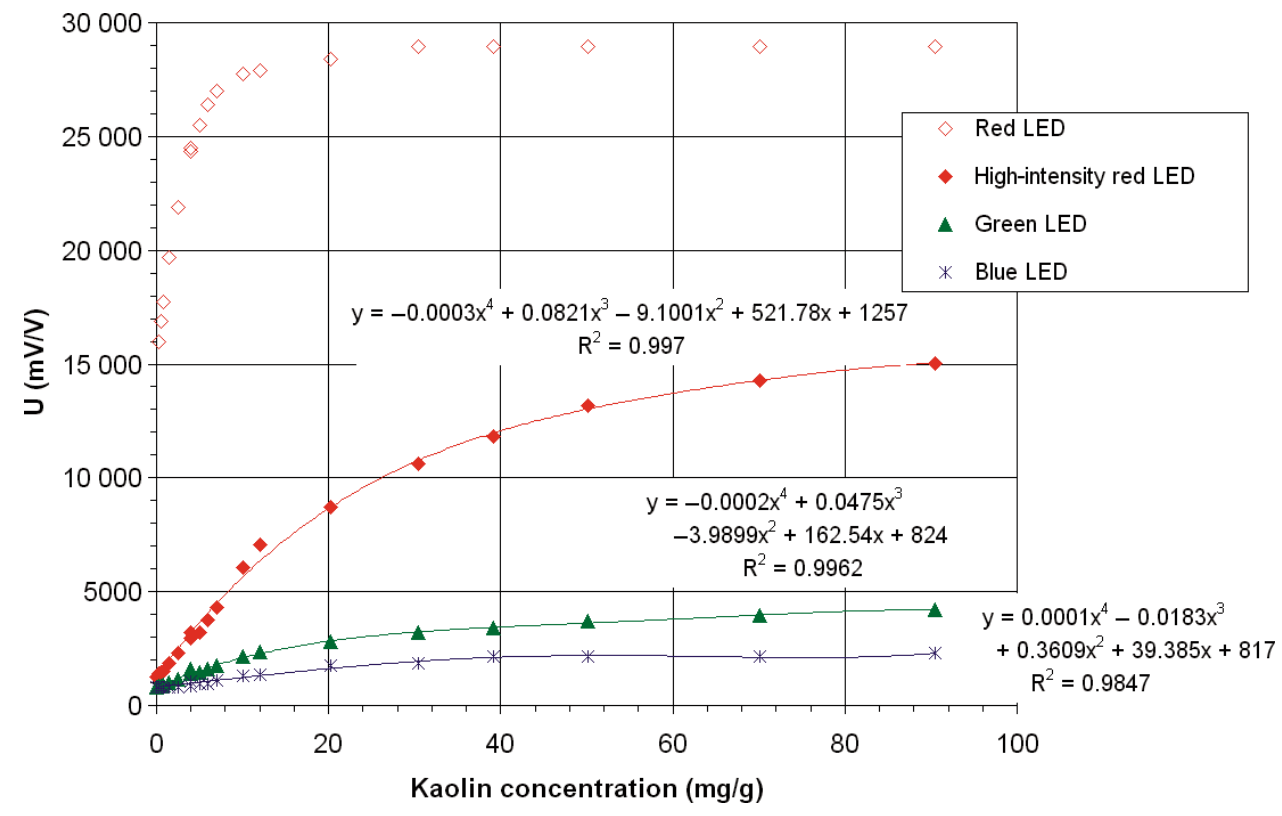

By using eq. [4], the relative error in calculation of kaolin concentration is lower than $5 \%$.

The sharp increase of the red LED output signal can be used to determine very low values of kaolin concentration. For a kaolin concentration smaller than $1.6 \mathrm{mg} / \mathrm{g}$, a linear correlation between red LED output signal, $U_{\text {red, }}$ and kaolin concentration can be defined by

$$
\begin{aligned}
{[5] \quad U_{\text {red }}[\mathrm{mv} / \mathrm{V}]=2810 C[\mathrm{mg} / \mathrm{g}]+} & 15441 \\
& \left(R^{2}=0.99, \quad N=5\right)
\end{aligned}
$$

The determination of kaolin concentration by eq. [5] is characterized by a $3 \%$ relative error. Two identical specimens at a kaolin concentration of $4 \mathrm{mg} / \mathrm{g}$ were compared to assess repeatability of the procedure. Figure 5 shows that repeatability is fairly good, as the two representation points are very close.

The output signals of the two red LEDs are simultaneously measured. Thus, it is possible to choose a suitable equation to minimize the relative error of kaolin concentration determination once the concentration range is known. For a kaolin 
Fig. 5. Relative output voltage for the four LEDs versus kaolin concentration (below $12 \mathrm{mg} / \mathrm{g}$ ).

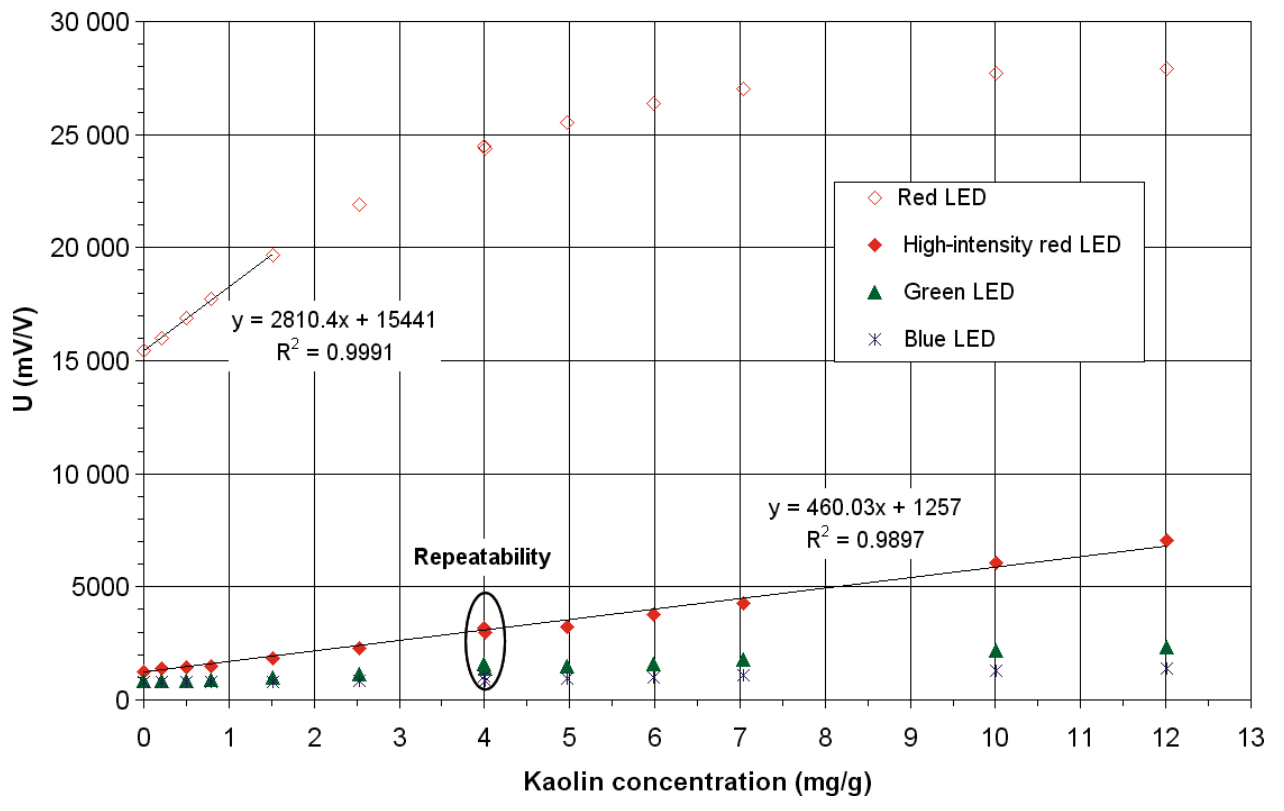

concentration up to $1.6 \mathrm{mg} / \mathrm{g}$, eq. [5] is used, with a maximum relative error of 3\%; eq. [4] is used for a concentration between 1.6 and $12 \mathrm{mg} / \mathrm{g}$ (maximum relative error 5\%); and a polynomial equation is used for solid concentrations higher than $12 \mathrm{mg} / \mathrm{g}$ and up to $90 \mathrm{mg} / \mathrm{g}$ (maximum relative error $3 \%$ ). For kaolin concentrations higher than $90 \mathrm{mg} / \mathrm{g}$, the output signal reaches a threshold value, which in turn, indicates the upper limit of the sensor's capacity. However, for these high values of kaolin concentration, even with a low value of fluid flow rate, the kaolin mass measurement can be performed by continuous weighing (for example, $90 \mathrm{mg} / \mathrm{g}$ of kaolin concentration and $0.2 \mathrm{~cm}^{3} \cdot \mathrm{s}^{-1}$ of fluid flow rate correspond to $18 \mathrm{mg} \cdot \mathrm{s}^{-1}$ of kaolin discharge, thus mass accuracy of a few milligrams is sufficient to determine the kaolin discharge).

\section{Influence of flow rate}

A mixture of water and kaolin at a solid concentration, $C=1 \mathrm{mg} / \mathrm{g}$ was tested under increasing fluid flow rates, ranging from 0.1 to $1.6 \mathrm{~cm}^{3} \cdot \mathrm{s}^{-1}$. It should be noted that with a $10 \mathrm{~cm}$ diameter sample and a unit hydraulic gradient, this range of flow rate corresponds to a hydraulic conductivity between $1.3 \times 10^{-5}$ and $2 \times 10^{-4} \mathrm{~m} / \mathrm{s}$. For the four LEDs, no significant variation of relative output voltage, $U$, was observed over the range of imposed flow rates.

\section{Influence of grain size and mineralogy of solid particles}

The influence of the type of solid particles was investigated for different fine concentrations with two clays (kaolin and bentonite) and a silt. A laser diffraction particle-size analyzer was used to measure the grain-size distribution of the three materials (see Fig. 6). For kaolin, grain-size distribution is within the range $0.1-17 \mu \mathrm{m}$, mean diameter $D_{50}=$ $4.5 \mu \mathrm{m}$, and uniformity coefficient is 4.62. The bentonite has a grain-size distribution between 0.1 and $56 \mu \mathrm{m}, D_{50}=$ $11 \mu \mathrm{m}$, and uniformity coefficient is 5. For silt, grain-size distribution is within the range $0.2-100 \mu \mathrm{m}, D_{50}=25 \mu \mathrm{m}$, and uniformity coefficient is 5.33. The chemical composition of kaolin, provided by the supplier, is $43 \% \mathrm{SiO}_{2}, 38 \% \mathrm{Al}_{2} \mathrm{O}_{3}$, and $1 \% \quad \mathrm{Fe}_{2} \mathrm{O}_{3}$. Bentonite composition is $60 \% \mathrm{SiO}_{2}, 15 \%$ $\mathrm{Al}_{2} \mathrm{O}_{3}$, and $4 \% \mathrm{Fe}_{2} \mathrm{O}_{3}$. The composition of silt is $55 \% \mathrm{SiO}_{2}$, $18 \% \mathrm{Al}_{2} \mathrm{O}_{3}$, and $9 \% \mathrm{Fe}_{2} \mathrm{O}_{3}$.

Figure 7 plots the relative output voltage for the high-intensity red LED for fines concentrations up to $90 \mathrm{mg} / \mathrm{g}$.

For the three soils studied, the high-intensity red output signal increases with increasing fines concentration. According to these measurements, a polynomial correlation between output signal and fines concentration can be established up to a fines concentration of $90 \mathrm{mg} / \mathrm{g}$ for bentonite and for silt (see equations in Fig. 7).

According to Bohren and Huffman (1998) the processes of light scattering and light absorption by a particle depend on the size of the particle, its shape, and the type of mineral. On Fig. 7, it can be observed that the calibration curve for silt crosses the calibration curve of kaolin, indicating the necessity of a calibration for each type of fines. For a real soil, the finer fraction can contain different clay minerals or silts. In that case, the calibration should be performed for the whole finer fraction and not separately for each component.

The relative output voltage for the high-intensity red LED is plotted as a function of kaolin, bentonite, or silt concentration smaller than $12 \mathrm{mg} / \mathrm{g}$ (Fig. 8).

With a fine concentration up to $12 \mathrm{mg} / \mathrm{g}$, the relative output voltage of the high-intensity red LED is approximately the same for bentonite and silt, and a linear correlation can by expressed (see equation in Fig. 8).

These calibration tests demonstrate clearly that the optical sensor has the capacity to measure the concentration of clay particles or cohesionless fine particles without significant influence of flow rate. Moreover, it is worth stressing that the measurements were performed under a vertical flow in the downward direction to avoid any deposition of the eroded particles inside the tube leading to and through the sensor (which is not the case for classical turbidimeters). 
Fig. 6. Grain-size distributions of tested fines.

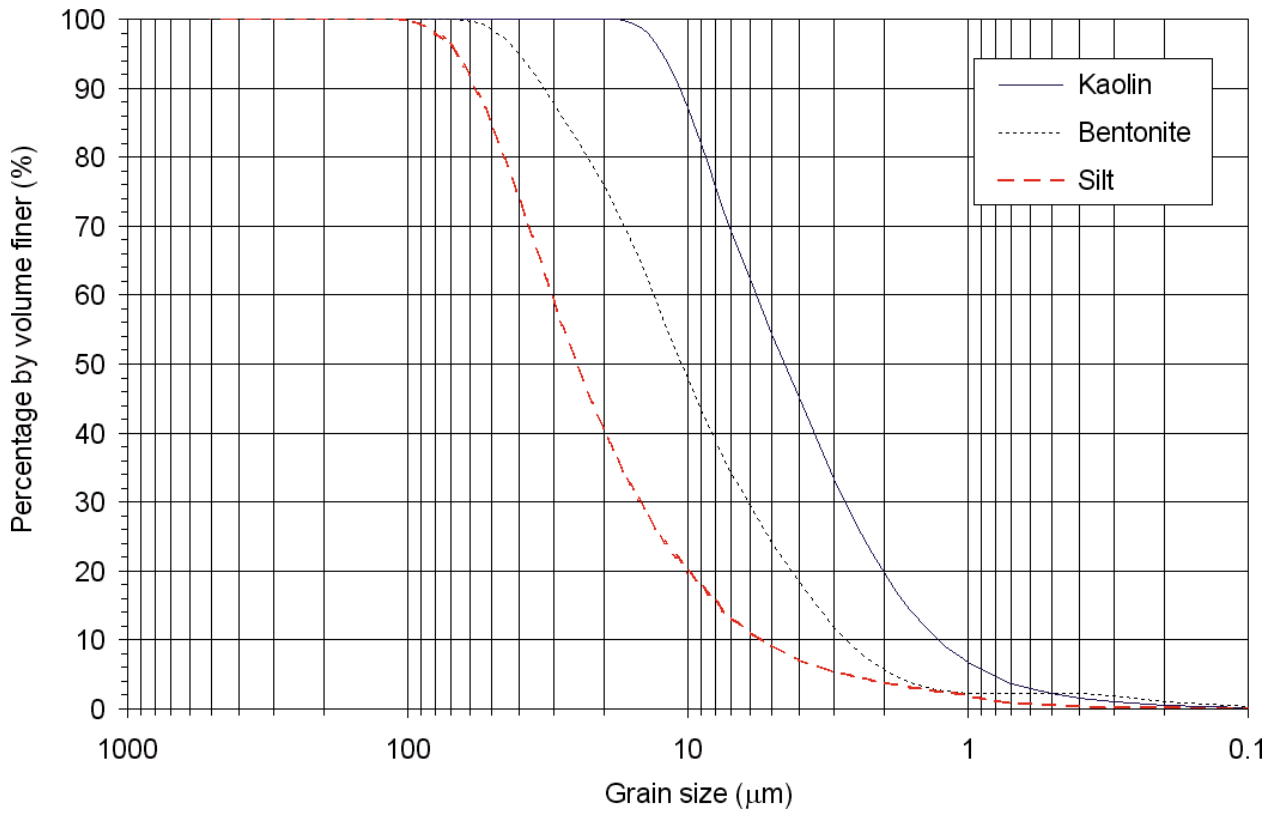

Fig. 7. Relative output voltage for the high-intensity red LED versus fines concentration.

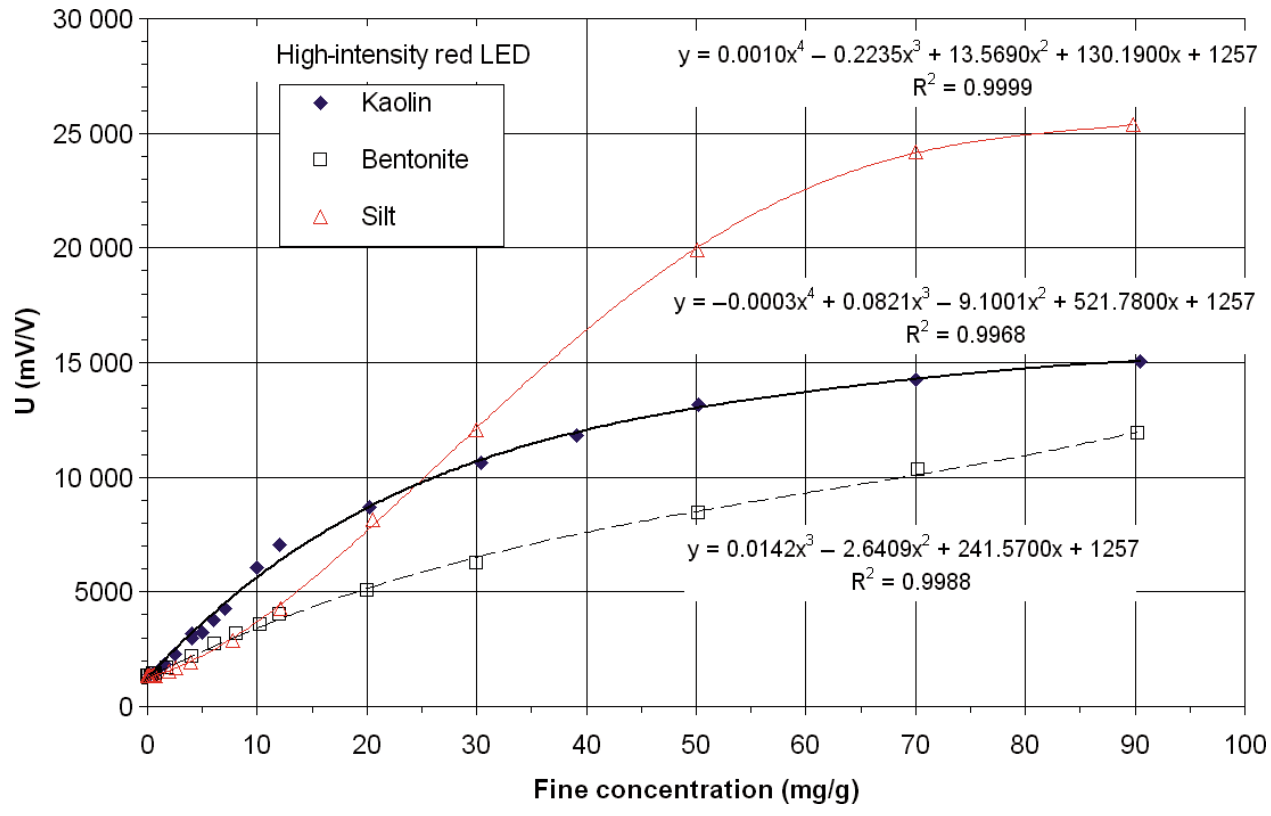

\section{Sand grain detection}

The process of fine particle erosion can also be accompanied by an erosion of coarser grains. In that case, it is necessary to distinguish fine particles (clay or silt) and sand grains in the effluent. Based on the wavelength dependence of the light absorbance, and after several comparisons of output signals of LEDs, it is proposed to relate grain dimension to the difference between output signals for green and blue LEDs.

This difference $(\Delta U)$ is determined for effluents containing an identical solid mass concentration $(4 \mathrm{mg} / \mathrm{g})$ but with five different clay and sand proportions. The mixer used may limit fine particles sedimentation but does not efficiently limit sand grains sedimentation. Thus, the process of effluent homogeneity does not allow producing a homogeneous effluent, and the sand grains pass occasionally through the sensor. Figure 9 shows peaks in the $\Delta U$ time output when sand appears within the effluent, and these variations can be measured even with a high clay concentration (see Fig. 10). The comparison of the voltages of each LED makes it possible to detect the presence of sand in the effluent and thus to distinguish sand grain from fine particle erosion.

To measure sand concentrations, two improvements to the proposed device are suggested for future testing. Effluent containing both fine particles and sand should be well stirred to create homogeneous effluents. The acquisition frequency should also be higher than $1 \mathrm{~Hz}$ to improve the accuracy of each measurement. 
Fig. 8. Relative output voltage for the high-intensity red LED versus fines concentration (below $12 \mathrm{mg} / \mathrm{g}$ ).

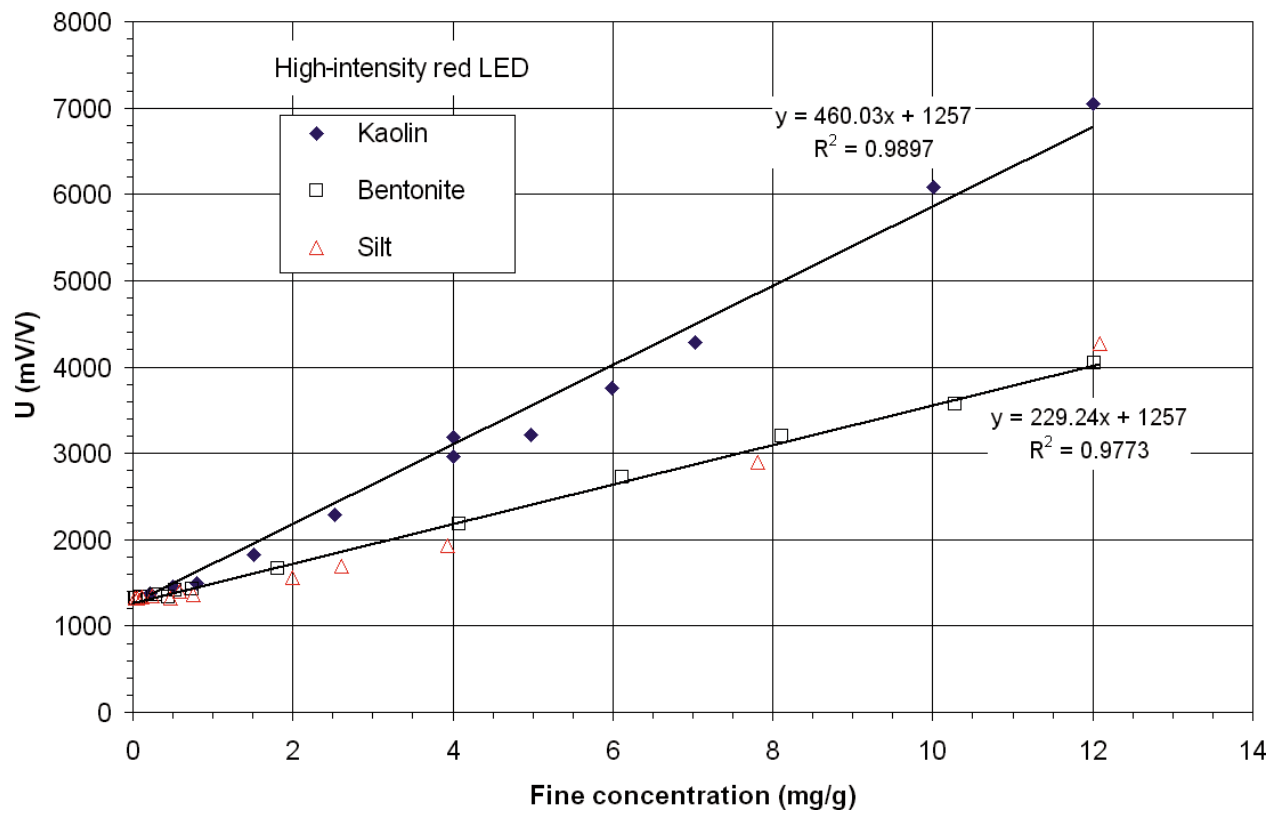

Fig. 9. Instantaneous values of difference between green and blue LEDs output for different effluents.

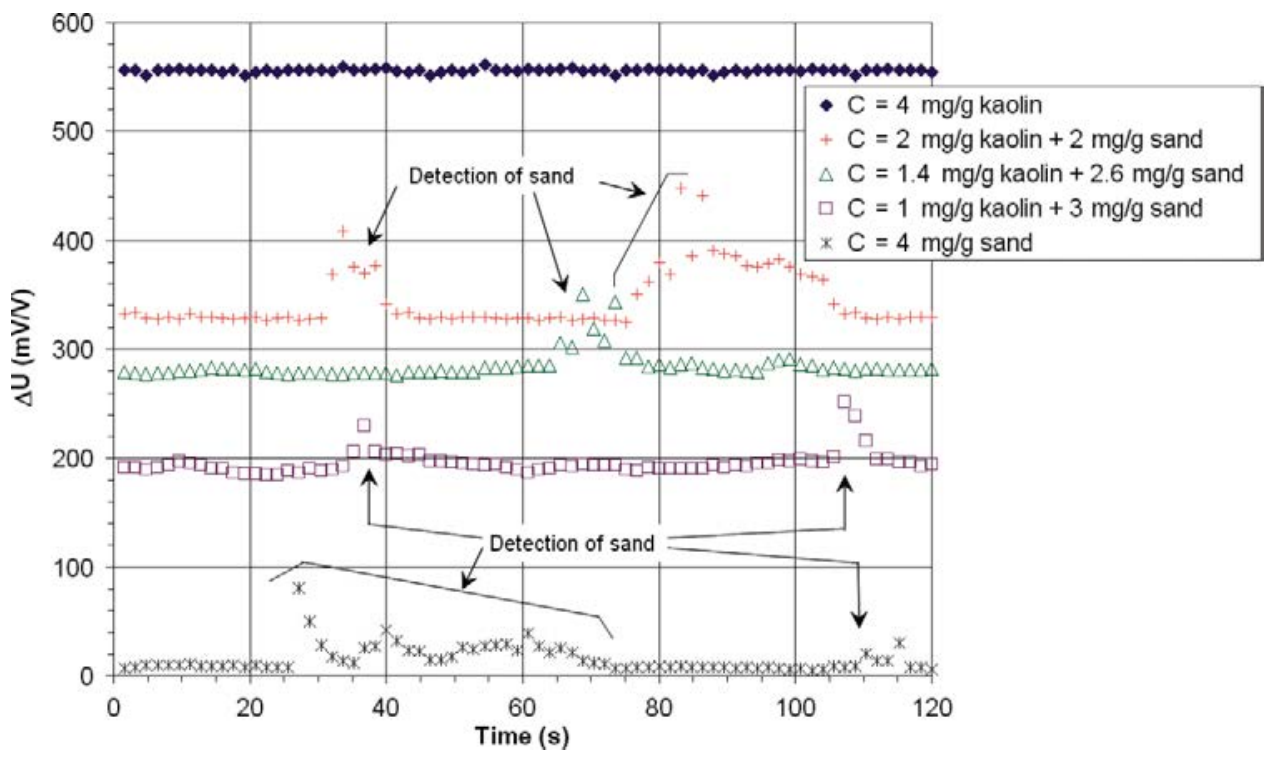

\section{Tests of soils containing large particles}

The inside diameter of the glass pipe used $\left(d_{\text {int }}=4 \mathrm{~mm}\right)$ limits the maximal diameter of the coarser fraction. With the objective to test gap graded soils or broadly graded soils with particle sizes ranging from clay size to gravel, a larger pipe should be used. In that case, the light intensity will be more attenuated because of the increase of the absorbing solution thickness, and finally the LDR output voltage could be insufficient. However, two modifications can be developed to test specimens containing large particles: the adjustment of the potentiometer can lead to a higher relative output voltage, and a higher light intensity can be produced by using a higher intensity LED or by using two identical LEDs.

\section{Relevance of multichannel optical sensor for characterization of suffusion initiation}

In the suffusion process, the coarse particles form a skeleton, and erosion occurs only for the finer particles in the pore space between the larger particles. With the objective to evaluate the likelihood of suffusion initiation, several geometric criteria based on the study of grain-size distribution have been proposed in literature. Wan and Fell (2008) concluded that the most widely used methods are conservative. These authors proposed an alternative method based on the ratios $D_{90} / D_{60}$ and $D_{20} / D_{5}$ (where $D_{90}$ is the sieve size for which $90 \%$ of the weighed soil is finer, $D_{60}$ is the sieve size for 
Fig. 10. Instantaneous values of difference between green and blue LEDs output for two high solid concentration effluents.

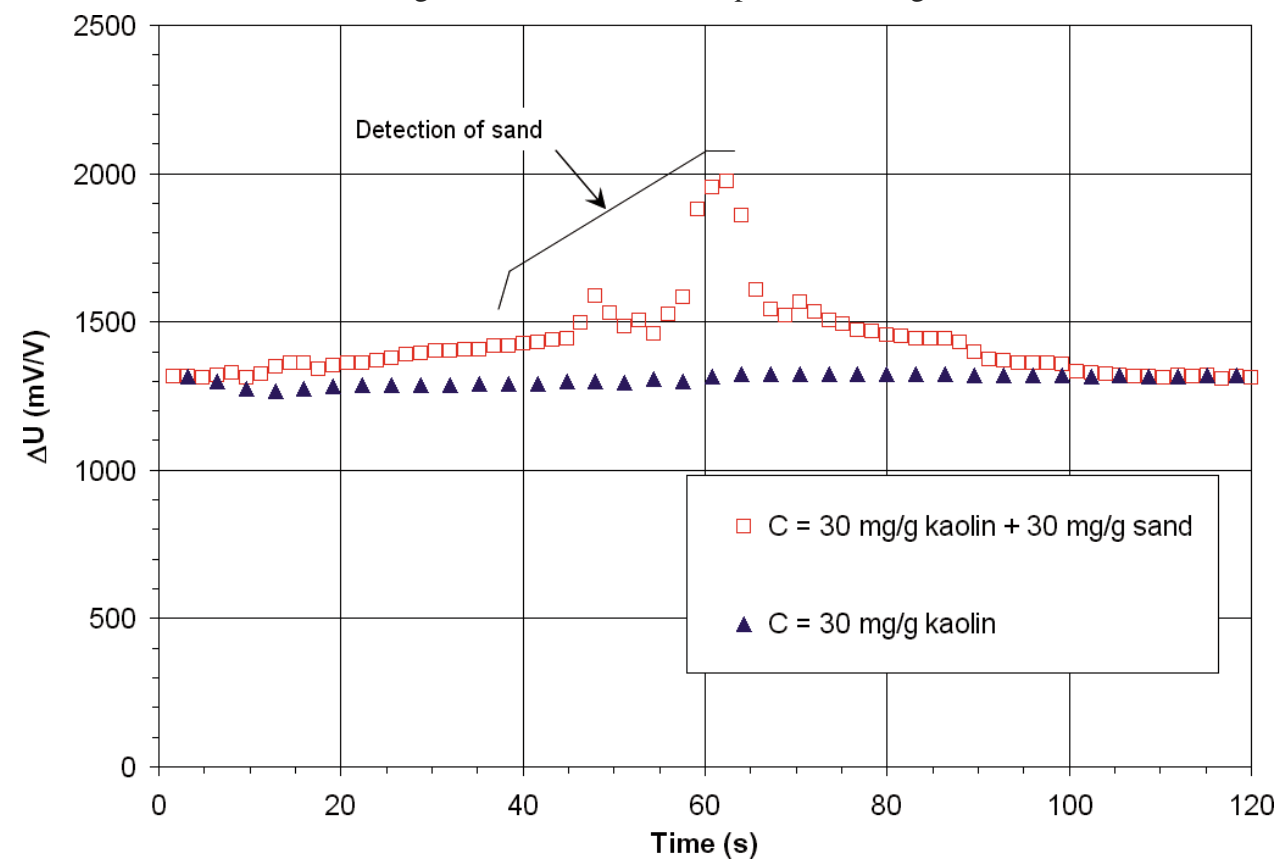

which $60 \%$ of the weighed soil is finer, $D_{20}$ is the sieve size for which $20 \%$ of the weighed soil is finer, and $D_{5}$ is the sieve size for which $5 \%$ of the weighed soil is finer). The $D_{90} / D_{60}$ ratio represents the slope of the coarse part of the particle-size distribution, and the $D_{20} / D_{5}$ is used to evaluate the filter action between the coarse fraction and the finer fraction. Depending on the values of these ratios, they defined three zones: one in which soils are stable, one in which soils are unstable, and a transition zone in between. According to Perzlmaier (2007), even if the transport of particles is geometrically feasible, the hydraulic load on particles has to be taken into account. This hydraulic load is often described by a hydraulic gradient, but because of the heterogeneity of the soils, Perzlmaier (2007) concluded that the pore velocity was the most descriptive parameter characterizing the hydraulic load. The mean pore velocity, $v_{\mathrm{p}, \mathrm{av}}$, can be expressed by

$$
\text { [6] } \quad v_{\mathrm{p}, \mathrm{av}}=\frac{v_{\mathrm{f}}}{n T}
$$

where $v_{\mathrm{f}}$ is the Darcian flow velocity; $n$ is porosity; and $T$ is tortuosity, which is the square ratio of the straight distance between two points to the effective length of flow path between these points. Tortuosity was estimated by Wittmann (cited by Perzlmaier 2007) as equal to $2 / \pi=0.6366$. The critical pore velocity is the pore velocity to start particle detachment. Perzlmaier (2007) calculated critical pore velocities derived from different theories that are found in the literature. He concluded that the critical pore velocity remains constant for particle diameters smaller than $0.1 \mathrm{~mm}$, and its value is about $10^{-3} \mathrm{~m} / \mathrm{s}$.

\section{Soils tested and testing program}

Table 1 summarizes the soils used in laboratory tests to characterize the suffusion process. As the sensor accuracy allows a fairly precise detection of clay particle erosion, a ser- ies of tests was performed using clayey sands. With such type of gap graded soils, the coarse fraction is composed of sand grains, and the fine fraction corresponds to the clay fraction. Tests were performed on different mixtures of $10 \%$ kaolin and $90 \%$ sand. Liquidity and plasticity limits of kaolin are $55 \%$ and $22 \%$, respectively. Three sands were tested, the first is a Fontainebleau sand (grain-size distribution within the range $75-425 \mu \mathrm{m}, D_{50}=207 \mu \mathrm{m}$, uniformity coefficient of 1.33 , and density of $26.5 \mathrm{kN} / \mathrm{m}^{3}$ ). A second sand, referred to as Loire sand, has a different grain-size distribution (grainsize distribution within the range $80-1 \mathrm{~mm}, D_{50}=440 \mu \mathrm{m}$, uniformity coefficient of 3.13 , and grain density of $26 \mathrm{kN} / \mathrm{m}^{3}$ ). The third sand (i.e., modified Loire sand) has the same grain-size distribution as the Fontainebleau sand, but it is composed of grains from the Loire sand.

By using the method proposed by Wan and Fell (2008) for assessing the potential of suffusion, the three mixtures would be defined as unstable.

Figure 11 shows the testing device used to study the suffusion process. The device consists of a triaxial cell coupled to a hydraulic system designed to force fluid through the samples in a downward direction under constant hydraulic gradients. A complete description of the device is given by Bendahmane et al. (2008).

The quantity of eroded particles can be very low. Thus, the measurement by weighing or by visual observation is not accurate enough to detect the initiation of suffusion. This triaxial device was equipped with the multichannel optical sensor described above. The optical sensor was placed at the end of the draining pipe at the base of triaxial setup. The small device dimensions allow the sensor to be placed vertically close to the base of the sample, and this positioning avoids any deposition of the eroded particles between the sample and optical sensor.

The specimen preparation phase was divided into three steps: production of the specimen, saturation, and finally con- 
Table 1. Summary of characteristics of tested mixtures and assessment of potential of suffusion using Wan and Fell (2008) method.

\begin{tabular}{llllllll}
\hline & \multicolumn{3}{c}{ \% weight of } & & \multicolumn{2}{c}{ Wan and Fell (2008) } \\
Type of sand & Symbol & kaolin & $D_{5}(\mu \mathrm{m})$ & $D_{20}(\mu \mathrm{m})$ & $D_{60}(\mu \mathrm{m})$ & $D_{90}(\mu \mathrm{m})$ & method \\
\hline Fontainebleau sand & $\mathrm{F}$ & 10 & 2.2 & 180 & 212 & 270 & Unstable \\
Loire sand & $\mathrm{L}$ & 10 & 2.2 & 210 & 450 & 700 & Unstable \\
Modified Loire sand & $\mathrm{ML}$ & 10 & 2.2 & 180 & 212 & 270 & Unstable \\
\hline
\end{tabular}

Fig. 11. Schematic diagram of the triaxial erodimeter.

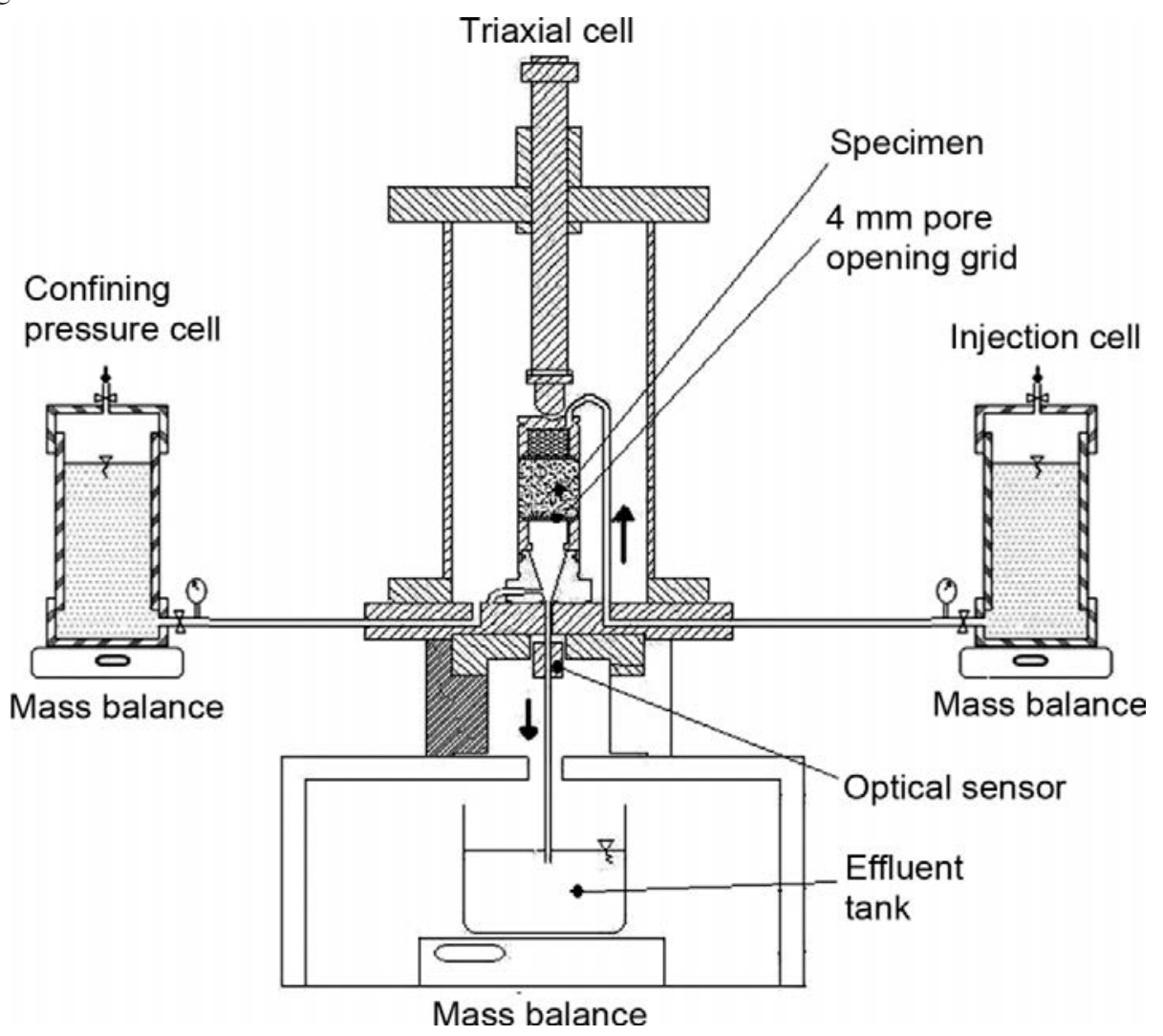

solidation. The sand grains are first mixed with a moisture content of $8 \%$. Then, while mixing continues, powder clay is progressively added, and mixing is then carried on for an additional $10 \mathrm{~min}$. After ensuring homogeneity of the grain-size distribution, the installation of specimens inside the cell required preliminary forming. The specimens were prepared using a single-layer semistatic compaction technique. The mixture was placed in a $50 \mathrm{~mm}$ diameter and $50 \mathrm{~mm}$ high mould and subsequently compressed under the action of two pistons until the initial fixed dry density (before consolidation) was reached. This initial dry density value was $17 \mathrm{kN} / \mathrm{m}^{3}$, and after consolidation under $100 \mathrm{kPa}$, the dry density was $17.5 \mathrm{kN} / \mathrm{m}^{3}$. In the triaxial cell device, the specimen was placed on a $4 \mathrm{~mm}$ pore opening grid. This pore opening allows the migration of all particles of sand and clay. A smaller pore opening grid would prevent the migration of sand grains, which in turn, would limit the initiation of suffusion process (Marot et al. 2009).

The saturation phase begins when a small $20 \mathrm{kPa}$ confinement pressure is applied to prevent any preferential leakage between the specimen and the membrane. Carbon dioxide was used to improve dissolution of gases into water, and finally saturation is completed using demineralized and dea-
Table 2. Applied hydraulic head and hydraulic gradient for suffusion tests.

\begin{tabular}{lll}
\hline $\begin{array}{l}\text { Soil } \\
\text { specimen }\end{array}$ & $\begin{array}{l}\text { Hydraulic } \\
\text { head }(\mathrm{cm})\end{array}$ & $\begin{array}{l}\text { Hydraulic } \\
\text { gradient, } i\end{array}$ \\
\hline F1 & 3 & 0.6 \\
F2 & 4 & 0.8 \\
F3 & 12.5 & 2.5 \\
F4 & 15 & 3 \\
L1 & 3 & 0.6 \\
L2 & 4 & 0.8 \\
L3 & 12.5 & 2.5 \\
ML & 15 & 3 \\
\hline
\end{tabular}

erated water. The whole saturation phase requires approximately $24 \mathrm{~h}$.

The isotropic confining pressure, $\sigma_{3}$, was increased in steps in conformity with standard NFP 94-074 (Association Française de Normalisation 1994) procedures to reach $100 \mathrm{kPa}$.

With the objective to recover grains, which could fall in the funnel-shaped draining system during the specimen preparation, a very small quantity of water was injected with low pressure by a lateral pore situated under the $4 \mathrm{~mm}$ pore open- 
Fig. 12. Instantaneous values of $(a)$ relative output voltage of red LED, $(b)$ difference between green and blue LEDs output, and (c) flow rate.
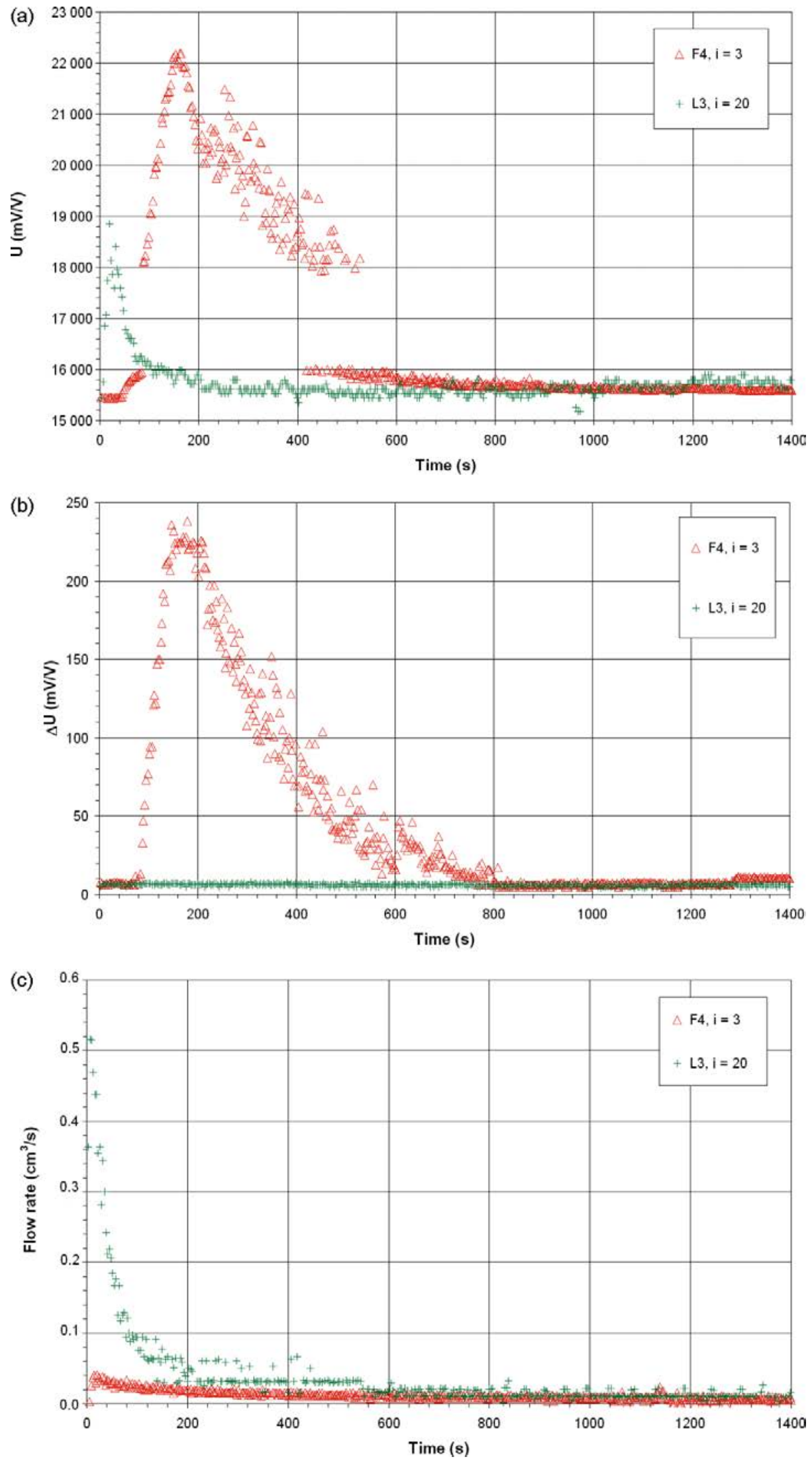
Fig. 13. Instantaneous values of ( $a$ ) kaolin concentration in effluent and (b) hydraulic conductivity for kaolin - Fontainebleau sand mixtures.
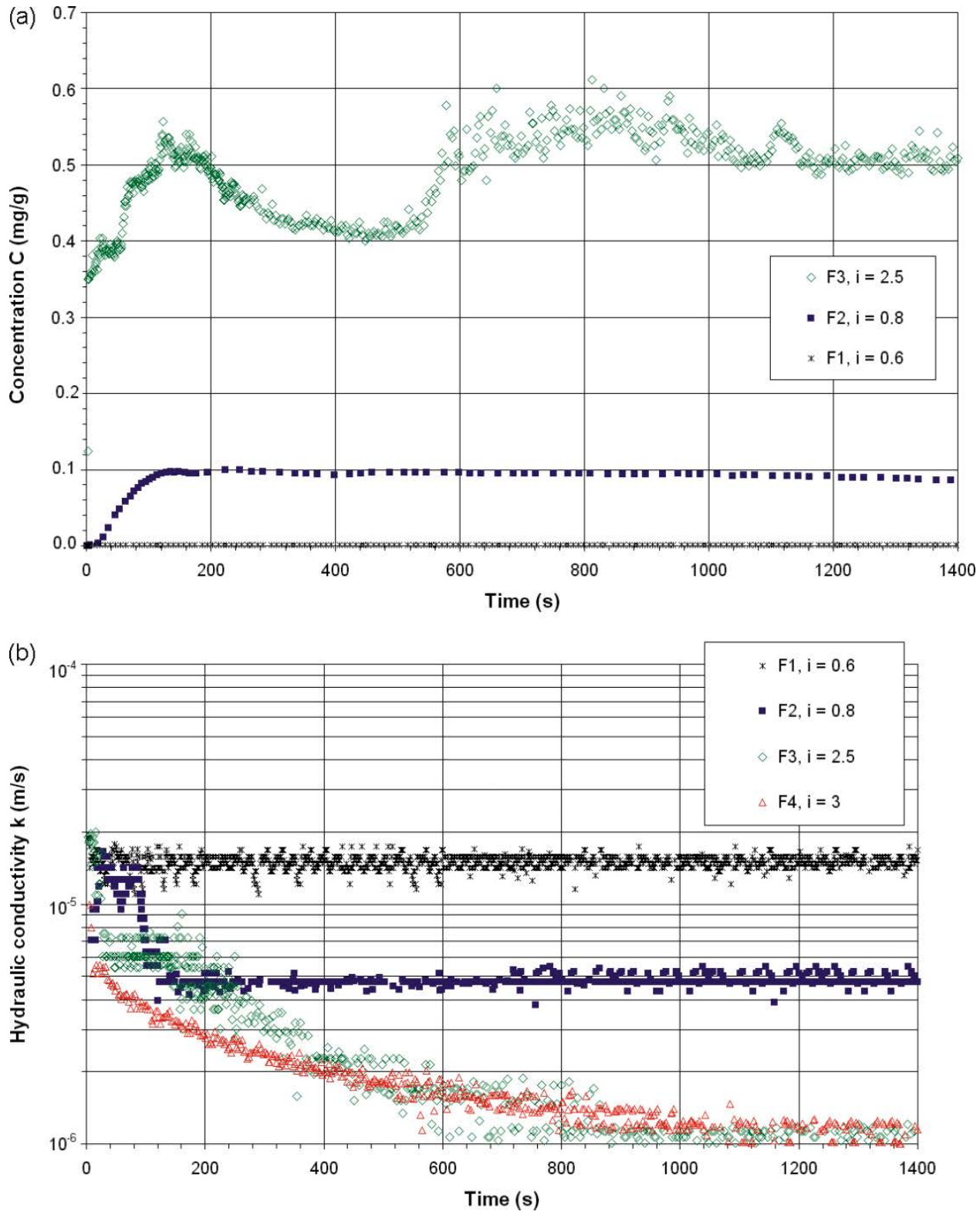

ing grid, and it was recovered by the effluent tank. Finally, the specimen was subjected to a hydraulic flow in a downward direction using demineralized and deaerated water to keep the injected fluid characteristics identical. Table 2 indicates the values of applied hydraulic head and hydraulic gradient for each performed tests. Four tests were performed on a mixture of Fontainebleau sand and kaolin (tests named F1F4). Three tests were performed on a mixture of Loire sand and kaolin (tests named L1-L3), and one test was performed on modified Loire sand (test LM).

\section{Test results}

Typical test results are shown on Fig. 12 in terms of the evolution of the following with time: $(a)$ output voltage for the red LED, $(b)$ difference between green and blue LEDs output, and $(c)$ injected flow rate. In the aforementioned, by the measurement of relative output voltage for the red LED, it is possible to determine the kaolin concentration smaller than $1.6 \mathrm{mg} / \mathrm{g}$. The difference between green and blue LEDs output $(\Delta U)$ is a useful indication of sand grain in the effluent. As shown in Fig. $12 b$, the great variations of $\Delta U$ indicate that sand grains were detected in the effluent during test F4. A detection of sand grains in the effluent shows that suffusion of clay particles is accompanied by sand erosion, and in that case, concentration of kaolin cannot be computed. The characterization of solid concentration in the effluent is completed by measurement of injected flow rate, which permits the determination of the hydraulic conductivity of the specimen. Thus, further interpretation of raw data can be done in two steps. The first step consists of verifying that no sand grains were detected in the effluent. In the second step, interpretation is performed in terms of variations of kaolin concentration in the effluent and of the hydraulic conductivity of the specimen with time.

Variations of kaolin concentration with time are plotted in Fig. $13 a$ for tests F1-F3. Test F1 was performed with a hy- 
Fig. 14. Instantaneous values of $(a)$ kaolin concentration in effluent and (b) hydraulic conductivity for kaolin - Loire sand mixtures.
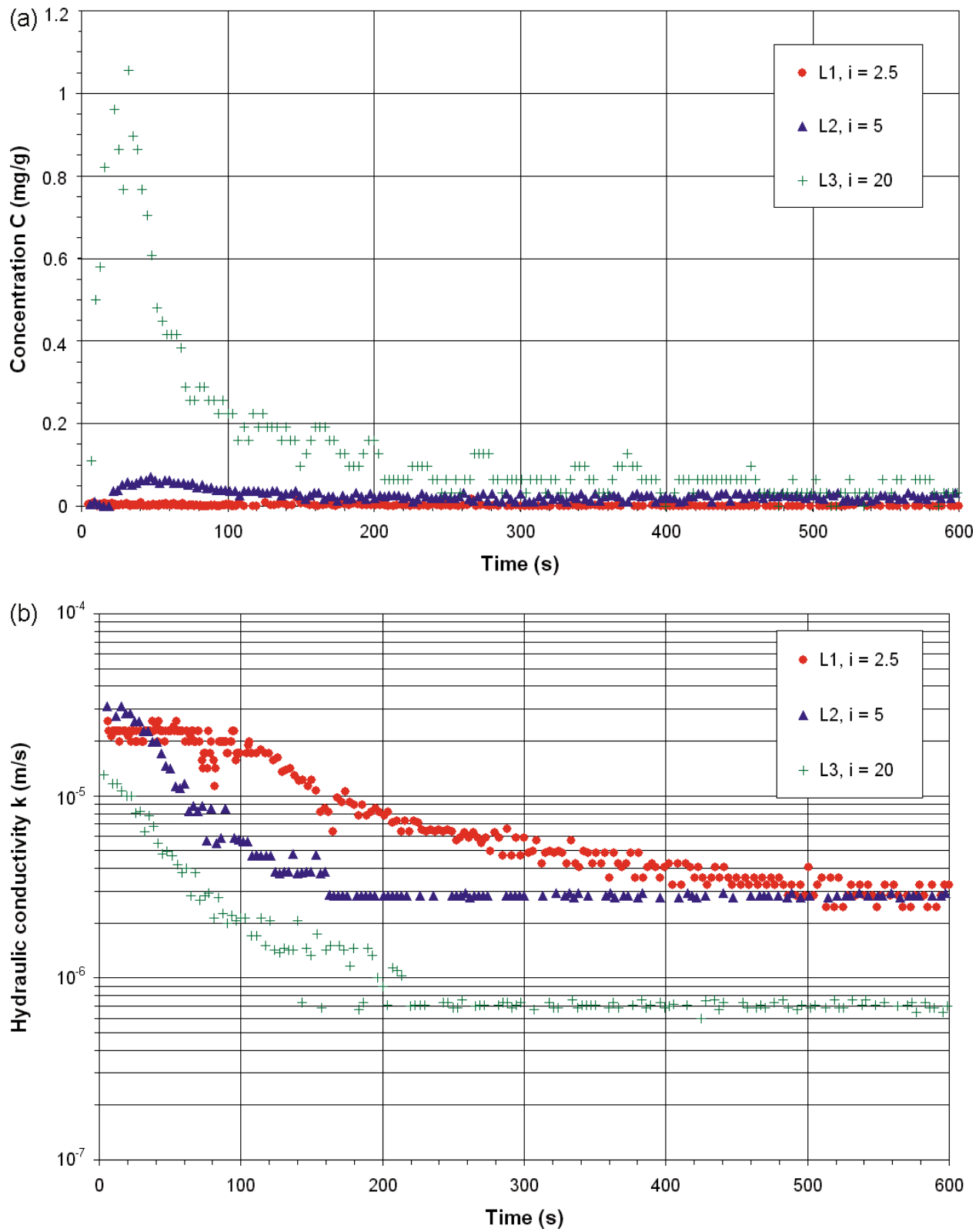

draulic gradient, $i=0.6$, and no erosion was detected. With $i=0.8$ (test F2), the kaolin concentration in the effluent increased steadily to reach $0.1 \mathrm{mg} / \mathrm{g}$ after $2 \mathrm{~min}$ of downward flow. After reaching a peak, the kaolin concentration decreased very slowly over time $\left(7 \times 10^{-2} \mathrm{mg} / \mathrm{g}\right.$ at $\left.t=30 \mathrm{~min}\right)$. With a hydraulic gradient of $i=2.5$ (test F3), kaolin concentration in the effluent was about $0.5 \mathrm{mg} / \mathrm{g}$, and when a hydraulic gradient of $i=3$ was applied (test F4) (not shown in Fig. $13 a$ but in Fig. 12), the suffusion of kaolin was accompanied by erosion of small amounts of sand grains.

Figure $13 b$ shows the variations of hydraulic conductivity with time. For tests F1-F4, the initial value of hydraulic conductivity was between $10^{-5}$ and $1.8 \times 10^{-5} \mathrm{~m} / \mathrm{s}$. For test $\mathrm{F} 1$, the hydraulic conductivity stayed constant for the whole duration of the test, about $1.5 \times 10^{-5} \mathrm{~m} / \mathrm{s}$, whereas for tests $\mathrm{F} 2-$ F4, it decreased with time.
Test results on Loire sand and kaolin mixtures are plotted on Fig. 14 in terms of the evolution of $(a)$ concentration of kaolin in the effluent and $(b)$ hydraulic conductivity with time. For $i=2.5$ (test L1), a very low kaolin concentration $\left(<10^{-2} \mathrm{mg} / \mathrm{g}\right)$ was measured in the effluent. During test L2, i.e., for $i=5$, the kaolin concentration in the effluent increased sharply to reach $7 \times 10^{-2} \mathrm{mg} / \mathrm{g}$ in $40 \mathrm{~s}$, followed by a rapid kaolin concentration decrease with time (at $t=$ $140 \mathrm{~s}, C=0 \mathrm{mg} / \mathrm{g}$ ). For a high value of hydraulic gradient, $i=20$ (test L3), the kaolin concentration increased up to $1.1 \mathrm{mg} / \mathrm{g}$ after a period of $30 \mathrm{~s}$. It was followed by a decrease over a few minutes $(C=0 \mathrm{mg} / \mathrm{g}$ at $t=470 \mathrm{~s})$. Figure $14 b$ shows that the hydraulic conductivity decreases with time, and in this case of kaolin - Loire sand specimens, the minimal value of hydraulic conductivity occurred well after the maximum value of eroded clay concentration was observed. 


\section{Suffusion and filtration: two coupled processes}

Without erosion (test F1), the hydraulic conductivity stays constant over time, but when a small kaolin concentration is detected in effluent (test F2, $C=0.1 \mathrm{mg} / \mathrm{g}$ ), the hydraulic conductivity decreases by a factor of 3 and reaches $5 \times 10^{-6} \mathrm{~m} / \mathrm{s}$. When the suffusion of kaolin grows (test F3, $C=0.5 \mathrm{mg} / \mathrm{g}$ ) or when suffusion is accompanied by sand erosion (test F4), the hydraulic conductivity decreases by a factor of 10 , with final values of hydraulic conductivity of the order of about $1.5 \times 10^{-6} \mathrm{~m} / \mathrm{s}$. It is worthwhile to stress that no significant variation of specimen volume was measured. Thus, as previously described by Reddi et al. (2000), the decrease in hydraulic conductivity during suffusion is attributed to particle redeposition and clogging processes within the specimen. Upon completion of each test, the specimen was divided into five layers, and the grain-size distribution of each layer was measured. No significant variation of grainsize distribution was present (the variation of fine percentage was less than $1 \%$ in comparison with the initial value), so the process of filtration of clay particles is diffuse within the specimens. Clay particles are generally plated shaped, and thus this property may induce a variation of hydraulic conductivity just by a modification of particle position. Therefore, we assume that displacements of small quantities of fine particles are sufficient to induce the decrease of hydraulic conductivity.

Considering tests F2 and F3, the comparison of eroded clay concentration and final value of hydraulic conductivity, $k_{\text {final }}$ (test F2: $C=0.1 \mathrm{mg} / \mathrm{g}, k_{\text {final }}=5 \times 10^{-6} \mathrm{~m} / \mathrm{s}$; test F3: $C=0.5 \mathrm{mg} / \mathrm{g}, k_{\text {final }}=1.5 \times 10^{-6} \mathrm{~m} / \mathrm{s}$ ), leads to the conclusion that the higher the eroded clay concentration, the greater the decrease of hydraulic conductivity. Therefore, the filtration of eroded clay particles may increase with the clay concentration in the interstitial flow.

\section{Grain size and coarse grain shape effects}

Tests F3 and L1 were both performed with $i=2.5$; the maximum value of kaolin concentration was $C_{\max }=0.6 \mathrm{mg} / \mathrm{g}$ with Fontainebleau sand, and $C_{\max }$ was $<10^{-2} \mathrm{mg} / \mathrm{g}$ with Loire sand. Therefore, in the case of the kaolin and Loire sand mixture, the maximum value of kaolin concentration is significantly smaller, and it can be also observed that kaolin concentration decreases rapidly with time.

In the case of specimens composed of Fontainebleau sand, the ratio of hydraulic conductivity at initial state to hydraulic conductivity at final state can reach 10 for a test characterized by a high eroded clay concentration (test F3). In the case of Loire sand, this ratio can reach 30 (test L3), with a final hydraulic conductivity value of $7 \times 10^{-7} \mathrm{~m} / \mathrm{s}$. Thus, the decrease of hydraulic conductivity, which is induced by filtration of eroded clay particles, depends on grain-size distribution of coarse fraction.

As shown in Fig. 15, grains of Loire sand are more angular than grains of Fontainebleau sand. Specimens tested in tests F2 and ML had the same grain-size distribution (Fontainebleau sand distribution), and both tests were performed with $i=0.8$. Figure $16 a$ represents the eroded clay concentration versus time for tests $\mathrm{ML}$ and F2. The maximum eroded clay concentration is $C_{\max }=0.02 \mathrm{mg} / \mathrm{g}$ with modified Loire sand, and $C_{\max }=0.1 \mathrm{mg} / \mathrm{g}$ with Fontainebleau sand. Therefore, the angularity of coarse fraction grains may con-
Fig. 15. Grains picture of (a) Loire sand and (b) Fontainebleau sand.
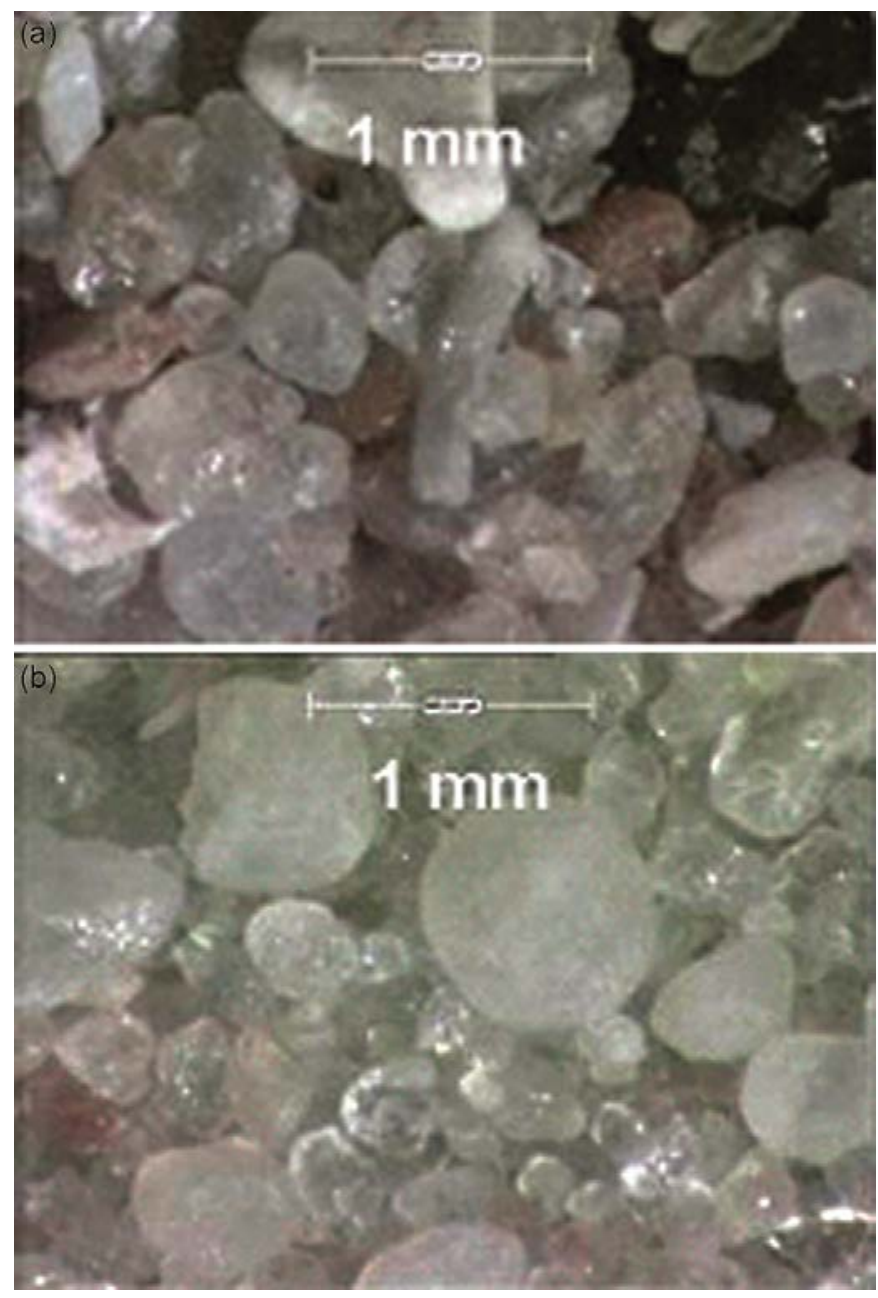

tribute to the increase of the erosion resistance of the tested soils by a factor of five.

Figure $16 b$ shows the instantaneous values of hydraulic conductivity for tests ML and F2. A higher magnitude of hydraulic conductivity decrease can be observed in the case of modified Loire sand, and the final value of hydraulic conductivity is $2 \times 10^{-6} \mathrm{~m} / \mathrm{s}$. Therefore, the grain shape also has an effect on hydraulic conductivity decrease for the tested soils. The angularity of coarse fraction grains may intensify the geometric blocking of eroded clay particles.

\section{Mean pore velocity}

The mean pore velocity is calculated using eq. [6] for all the mixtures. The mean pore velocity for each test was plotted on Fig. 17 as a function of the values of kaolin concentration in the effluent. The critical values of the mean pore velocity are indicated by the arrows on Fig. 17. Because the optical sensor has the ability to distinguish clay particles and sand grains in the effluent, it was possible to represent only specimens characterized by clay suffusion.

For specimens where the grain-size distribution of coarse fraction corresponded to Fontainebleau sand (tests F1, F2, F3, and ML), suffusion was initiated for a mean pore velocity within the range of $3 \times 10^{-5}$ to $10^{-3} \mathrm{~m} / \mathrm{s}$. Kaolin and Loire sand 
Fig. 16. Instantaneous values of $(a)$ kaolin concentration in effluent and $(b)$ hydraulic conductivity for kaolin - Fontainebleau sand and kaolin - modified Loire sand mixtures.
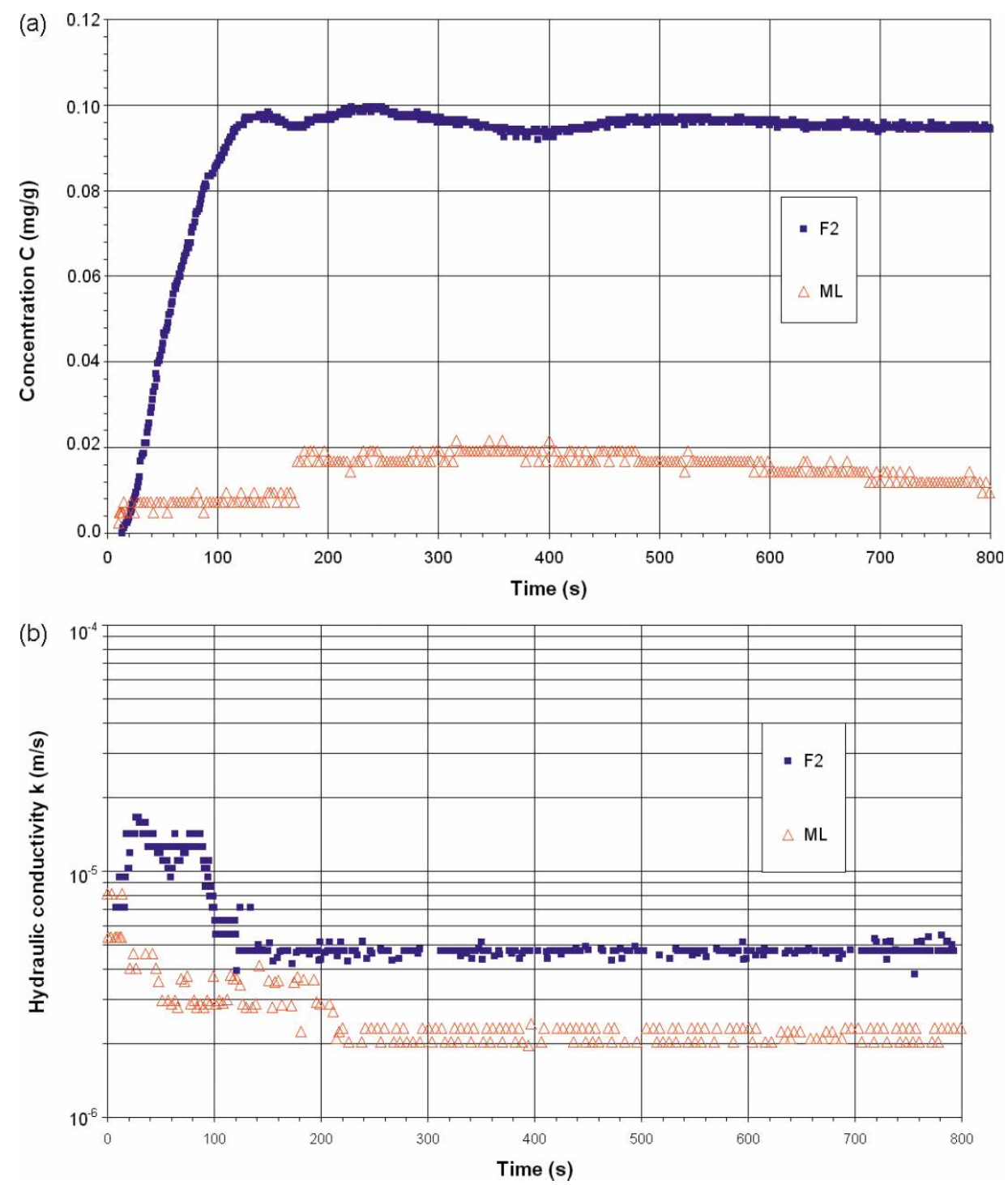

Fig. 17. Mean pore velocity versus kaolin concentration for specimens subjected to suffusion. Arrows show initiation of suffusion process.

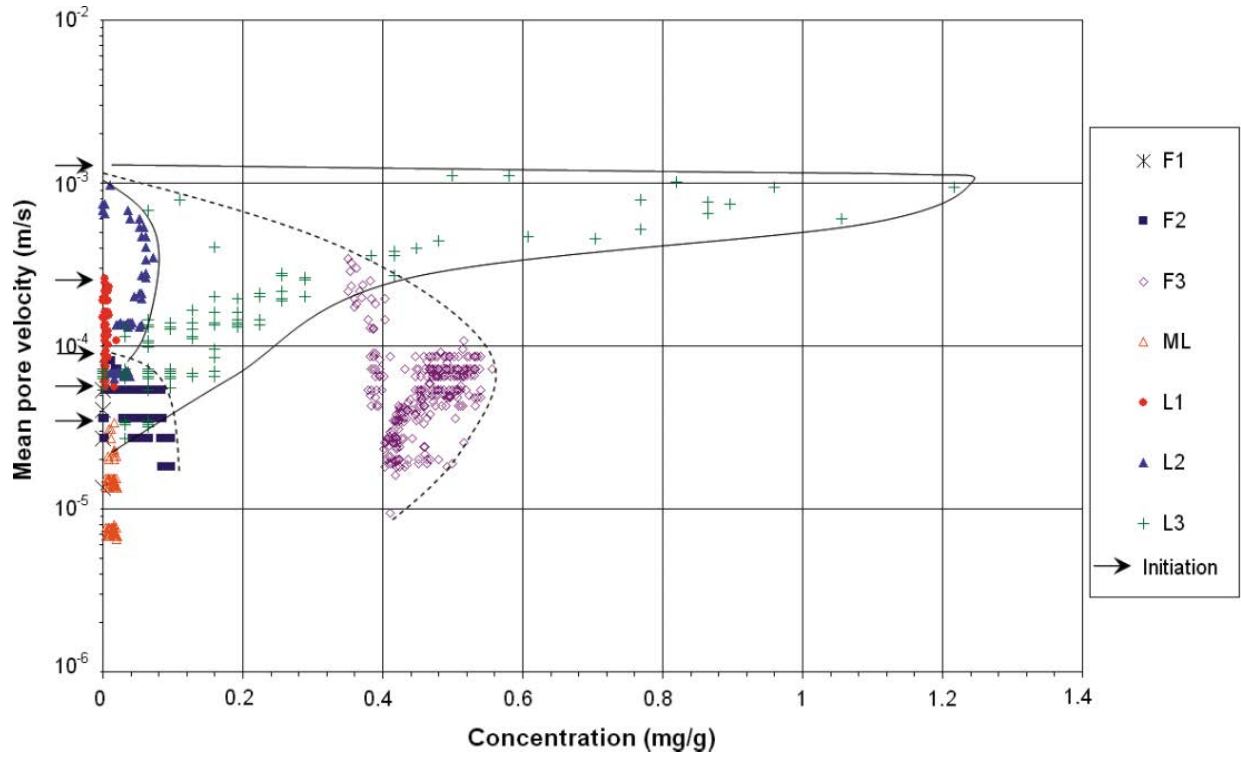


specimens were characterized by critical mean pore velocities between $3 \times 10^{-4}$ and $10^{-3} \mathrm{~m} / \mathrm{s}$. Therefore, a suffusion of clay particles can appear for pore velocity smaller than $10^{-3} \mathrm{~m} / \mathrm{s}$, and its value depends on grain-size distribution of the coarse fraction. Owing to the filtration process during suffusion process, a part of eroded clay particles is filtrated, which induces the decrease of mean pore velocity as hydraulic conductivity decreases. For Fontainebleau sand, mean pore velocity varies between $7 \times 10^{-6}$ and $3 \times 10^{-4} \mathrm{~m} / \mathrm{s}$. For kaolin and Loire sand specimens, the mean pore velocity is between $3 \times 10^{-5}$ and $10^{-3} \mathrm{~m} / \mathrm{s}$.

\section{Conclusions}

A multichannel optical sensor was designed to quantify the instantaneous fine particles concentration of effluents.

Several tests on different mixtures of water and three types of fine particles revealed that the proposed optical sensor has the capacity to measure a large range of fines concentration in the effluent without a significant influence of flow rate. Moreover, this sensor allowed one to distinguish between the sand grain and fine particle in the effluent.

Because of the compact size of the sensor and the low cost of its components, the sensor can be easily used in any laboratory test device. The optical sensor can be used in association with several devices to characterize the initiation and the development of fine particle erosion.

A triaxial device equipped with this optical sensor is used to characterize the suffusion process. Given the accuracy of the optical sensor, the influence of grain-size distribution on initiation and development of suffusion were studied. The coarse grain shape also seems to have an influence on suffusion development, but further studies are required to confirm this influence.

The suffusion of clay particles is accompanied by filtration of part of the eroded clay particles, which induces a hydraulic conductivity decrease. The hydraulic conductivity decreases more with a higher concentration of eroded particles in the interstitial flow. Coarse grain distribution and grain angularity also influence the suffusion process.

When high hydraulic gradients are applied, clay suffusion can be accompanied by sand erosion.

For the tested clayey sand specimens (10\% of kaolin), the critical pore velocity is between $3 \times 10^{-5}$ and $10^{-3} \mathrm{~m} / \mathrm{s}$. Therefore, the value of critical pore velocity can be smaller than the value of $10^{-3} \mathrm{~m} / \mathrm{s}$ mentioned in the literature.

The definition of suffusion initiation constitutes an important and still unanswered question, thus further studies are required to definitely characterize suffusion initiation.

\section{Acknowledgements}

The authors wish to express their gratitude to D. Fournol, Technician at the University of Nantes, Saint-Nazaire, France, for his assistance in the assembly of the optical sensor. Thanks are also extended to Professor A. Alexis from the University of Nantes for his fruitful advice. This project was sponsored by the French National Research Agency (ANRERINOH).

\section{References}

Agence nationale de la recherche. 2009. Érosion interne dans les ouvrages hydrauliques (ERINOH), ANR-PGCU, Axe 1. Essais de laboratoire, Agence nationale de la recherche (ANR), Paris, France. Report ANR-IREX-RGC\&U.

Association Française de Normalisation. 1994. Essais à l'appareil triaxial de révolution. Standard NFP 94-074. Association Française de Normalisation (AFNOR), Saint-Denis, France.

Bendahmane, F., Marot, D., and Alexis, A. 2008. Parametric study of suffusion and backward erosion. Journal of Geotechnical and Geoenvironmental Engineering, 134(1): 57-67. doi:10.1061/ (ASCE)1090-0241(2008)134:1(57).

Bohren, C.F., and Huffman, D.R. 1998. Absorption and scattering of light by small particles. Wiley Professional Paperback Edition. John Wiley \& Sons, Inc., New York.

Foster, M., Fell, R., and Spannagle, M. 2000. The statistics of embankment dam failures and accidents. Canadian Geotechnical Journal, 37(5): 1000-1024. doi:10.1139/t00-030.

Kenney, T.C., and Lau, D. 1985. Internal stability of granular filters. Canadian Geotechnical Journal, 22(2): 215-225. doi:10.1139/t85-029.

Li, M. 2008. Seepage induced failure of widely graded cohesionless soils. Ph.D. thesis, Department of Civil Engineering, The University of British Columbia, Vancouver, B.C.

Marot, D., Bendahmane, F., Rosquoët, F., and Alexis, A. 2009. Internal flow effects on isotropic confined sand-clay mixtures. Soil \& Sediment Contamination, an International Journal, 18(3): 294-306. doi:10.1080/15320380902799524.

Moffat, R., and Fannin, J. 2006. A large permeameter for study of internal stability in cohesionless soils. Geotechnical Testing Journal, 29(4): 273-279.

Perzlmaier, S. 2007. Hydraulic criteria for internal erosion in cohesionless soil. In Internal erosion of dams and their foundations. Edited by R. Fell and J.J. Fry. Taylor \& Francis, Oxfordshire, UK. pp. 179-190.

Reddi, L.N., Lee, I.-M., and Bonala, M.V.S. 2000. Comparison of internal and surface erosion using flow pump test on a sandkaolinite mixture. Geotechnical Testing Journal, 23(1): 116-122. doi:10.1520/GTJ11129J.

Sail, Y., Marot, D., Sibille, L., and Alexis, A. 2011. Suffusion tests on cohesionless granular matter. European Journal of Environmental and Civil Engineering, 15(5): 799-817. doi:10.3166/ejece.15.799817.

Skempton, A.W., and Brogan, J.M. 1994. Experiments on piping in sandy gravels. Géotechnique, 44(3): 440-460. doi:10.1680/geot. 1994.44.3.449.

Thomas, O., and Burgess, C. 2007. UV-visible spectrophotometry of water and wastewater. Techniques and instrumentation in analytical chemistry. Elsevier, Amsterdam, the Netherlands. Vol. 27.

Wan, C.F., and Fell, R. 2004. Experimental investigation of internal instability of soils in embankment dams and their foundations. University of New South Wales, Sydney, Australia. Uniciv Report R-429.

Wan, C.F., and Fell, R. 2008. Assessing the potential of internal instability and suffusion in embankment dams and their foundations. Journal of Geotechnical and Geoenvironmental Engineering, 134(3): 401-407. doi:10.1061/(ASCE)1090-0241(2008)134:3(401). 